\title{
Qualitative Inheritance of External Fruit Traits in Watermelon
}

\author{
Lingli Lou and Todd C. Wehner ${ }^{1}$ \\ Department of Horticultural Science, North Carolina State University, \\ Raleigh, NC 27695-7609
}

Additional index words. rind, pattern, color, gene

\begin{abstract}
Genes for watermelon [Citrullus lanatus (Thunb.) Matsumura \& Nakai] fruit traits have been identified since the 1930s. We conducted a study of fruit traits including fruit stripe width, stripe color, rind color, fruit shape, and blossom end shape (concave vs. convex). Ten watermelon cultivars (inbred lines) were used as parents. Several new genes or alleles were discovered. A series of alleles at the $g$ locus is proposed to explain the inheritance of fruit rind pattern: $G$ (medium or dark solid green), $g^{W}$ (wide stripe), $g^{M}$ (medium stripe), $g^{N}$ (narrow stripe), and $g$ (solid light green or gray). The dominance series is $G>g^{W}>g^{M}>g^{N}>g$. Another series of alleles at the $o b$ locus is proposed for the fruit shape: allele $O b^{E}$ for elongate fruit, which is the most dominant; allele $O b^{R}$ (not the same as the $o$ gene for round) for the round fruit; and allele $o b$ for oblong fruit, which is the most recessive. Gene $\mathrm{csm}$ is proposed for the clear stripe margin in the cultivar Red$\mathrm{N}-$ Sweet and is recessive to the blurred stripe margin $(\mathrm{Csm})$ in 'Crimson Sweet', 'Allsweet', and 'Tendersweet Orange Flesh'.
\end{abstract}

Watermelon [Citrullus lanatus (Thunb.) Matsumura \& Nakai] is a major vegetable crop cultivated as an annual in warm regions worldwide. Watermelon accounts for $6.8 \%$ of vegetable production area around the world (Guner and Wehner, 2004). Harvested area decreased $15 \%$ from 2002 to 2012 , but total production has remained constant around 2 million $\mathrm{Mg}$. The watermelon industry has increased in value from $\$ 497$ to $\$ 520$ million from 2003 to 2012 in the United States (USDA, 2004, 2012).

Watermelon has a small genome: $4.2 \times$ $10^{8}$ base pair for the 22-chromosome diploid (Arumuganathan and Earle, 1991). The watermelon genome has been sequenced and 23,440 predicted protein-coding genes were identified (Guo et al., 2013). Genetic studies since the 1930s have identified more than 100 genes. The genes control traits in seed and seedling, vine, flower, and fruit, as well as resistance to diseases, insects, and stress (Wehner, 2008a). The genes of watermelon have been described in several reviews (Guner and Wehner, 2004; Wehner, 2008a, 2012).

The rind of watermelon fruit can be striped or solid colored. The solid rind patterns include solid dark green as in 'Black Diamond', solid medium green as in 'Peacock Shipper', solid light green as in 'King\&Queen', gray (medium green reticulations on a light green background) as in 'Charleston Gray', or golden as in 'Royal Golden' (Guner and Wehner, 2003, 2004; Gusmini and Wehner, 2006a,

\footnotetext{
Received for publication 25 Jan. 2016. Accepted for publication 27 Mar. 2016

We gratefully acknowledge Tammy L. Ellington for assistance with the field tests and Laura Arellano for assistance with greenhouse pollinations.

${ }^{1}$ Corresponding author. E-mail: todd_wehner@ ncsu.edu.
}

2006b). In some reports, gray rind has been described as yellowish white or yellowish green (Porter, 1937).

The stripes of watermelon can be characterized by stripe width (narrow, medium, or wide), stripe color, and background color (dark green, medium green, or light green). Since the stripe patterns are alternating light and dark-colored stripes on the rind, there is ambiguity deciding which are the stripes. In this study, we considered the dark area to be the stripes. This follows the observation that the dark areas cover the vascular tissue below the fruit surface (Korn, 2007). Although the developmental basis of the longitudinal stripe pattern in watermelon has not been studied in detail, a clonal mosaic model was proposed based on observational evidence (Korn, 2007). In both young and mature fruit of 'Ruby Red', the vascular bundles run beneath the dark green reticular stripes, showing the association of the two. This association is also found on watermelon pedicels. Korn (2007) suggested that the vascular bundles are a prepattern determining the stripes on the fruit surface. The reticulations in the stripe composed of sets of polygons give the basis of the clonal mosaic model. This clonal mosaic model hypothesizes that a cell gives rise to a clone of various types of cells (the polygon) with dark green border, light green center, and medium green region between the two. This model explains the formation of the multiple-celled polygons that compose the darker green stripes with reticulations on the fruit of 'Ruby Red'.

Besides being striped or solid colored, there are additional modifications to watermelon rind, such as the netted reticulations within stripes or on the whole fruit surface, mottling (irregularly shaped light color) on the otherwise solid dark-colored background, ground spot color, furrowed fruit surface, and explosive rind. The reticulations are found on many cultivars, including some light green cultivars such as Charleston Gray, where the reticulations are more intensive near the surface of the vascular bundle and less intensive on the areas between vascular bundles. The reticulations are also found on the medium-green stripes of some striped cultivars, such as Ruby Red, China 23 (the typeline for the $p$ gene) (Weetman, 1937), Crimson Sweet (the medium-width stripe cultivar in our experiment), and in the surrounding area of the ground spot of the otherwise solid dark green fruit such as 'Black Diamond'. It is possible that the dark green cultivar Black Diamond is actually reticulated, but the reticulations are not visible due to the dark rind color.

Consumers often express a preference for particular rind patterns. Striped rind pattern is usually preferred over other patterns such as gray. Resistance to bacterial fruit blotch was associated with cultivars having dark rather than light rind; however, the effect may have been a nongenetic association (Wehner, 2008b). Rind toughness is important for postharvest handling and shipping. Other external rind traits, such as furrowed fruit surface and different fruit shapes, also affect customer acceptance.

Studies by Porter (1937) and Weetman (1937) identified three alleles at the $g$ locus that produce solid dark green $(G)$, striped $\left(g^{s}\right)$, or gray $(g)$ rind pattern. The gray rind pattern has been described as light green in some studies. Solid dark green $(G)$ is dominant to striped $\left(g^{s}\right)$ and gray $(g)$. Striped rind pattern $\left(g^{s}\right)$ is dominant to gray $(g)$. The allele $G$ is from 'California Klondike', $g$ is from 'Thurmond Gray', and $g^{s}$ is from 'Golden Honey'. Recently, Kumar and Wehner (2011) found a second gene controlling the dark green rind vs. gray rind pattern. The $g$ gene is considered $g-l$ and the second gene $g$-2, from type-line 'Minilee'. The $g-1$ and $g-2$ genes produce the gray rind pattern. The others ( $G-1 G-1 G-2 G-2$, $G-1 G-1 g-2 g-2$, and $g-1 g-1 G-2 G-2)$ produce dark green rind pattern.

The gene ins from 'Navajo Sweet' (Ins from 'Crimson Sweet') produces intermittent stripes, starting with narrow dark green stripes at the peduncle end of the fruit and becoming irregular in the middle and nearly absent at the blossom end of the fruit (Gusmini and Wehner, 2006a).

Very narrow stripe on a light background on the rind of 'Japan 6' is called pencilled $(p)$ phenotype. It is recessive to the netted (medium green-colored network) $(P)$ rind pattern of 'China 23' when disregarding the dark stripes on the light background (Weetman, 1937).

Another rind gene described by Weetman (1937) is the $m$ gene from 'Long Iowa Belle' for the particular randomly distributed and irregularly shaped greenish-white mottling pattern. The mottling pattern differs from the rest of the fruit not only in color but also in the character of the epidermis. This special phenotype was called the 'Iowa Belle' 
phenotype by Weetman (1937). It was recessive to the nonmottling trait of 'Japan 4' and 'China 23' when disregarding the stripes on 'China 23' (Weetman, 1937). Since many of the type-lines used by Weetman (1937) are not available, it is not possible to study the $p$ and $m$ genes.

'Moon and Stars' has large yellow spots (moons) and small yellow spots (stars) over a dark green background, which occurs on the fruit rind as well as the foliage (cotyledons and true leaves). The trait is controlled by the gene $(S p)$, which is dominant to the uniform green color $(s p)$ of 'Allsweet' (Poole, 1944; Rhodes, 1986). The gene $Y b$ produces the yellow belly trait on the fruit of 'Black Diamond Yellow Belly'. This cultivar has a dark yellow to orange-colored ground spot on a solid dark green fruit and is dominant to the usual creamy white ground spot $(y b)$ of 'Black Diamond' (Gusmini and Wehner, 2006a).

The golden gene go produces a golden yellow color of mature fruit as well as on the older leaves of 'Royal Golden'. This gene is recessive to the normal green leaves and fruit (Go) of 'NC 34-9-1' and 'NC 34-2-1' (Barham, 1956; Robinson et al., 1976). Watermelon fruit with furrowed parallel indentations $(f)$ was found to be recessive to the smooth surfaced fruit $(F)$. Since type-lines were not given in the original reference, 'Stone Mountain' or 'Black Diamond' might be used for $f$, and 'Mickylee' for $F$ (Poole, 1944; Wehner, 2008a). The gene $e$ from 'California Klondike' produces an explosive rind that is tender and bursting when cut. It is recessive to tough rind $(E)$ from 'Thurmond Gray' and 'Golden Honey' (Poole, 1944). The explosive trait was not correlated with fruit rind thickness, but with rind cell wall thickness (Kenny and Porter, 1941).

Watermelon fruit shape can be elongate, oval, round, or oblong, based on the length to width ratio. Weetman (1937) investigated the inheritance of fruit shape in the families of 'Long Iowa Belle' (elongate fruit) $\times$ 'Round Iowa Belle' and 'China 23' (round fruit), as well as 'Long Iowa Belle' $\times$ 'Japan 6' and $\times$ 'Japan 4' (round fruit). He found that elongate fruit shape $(O O)$ was incompletely dominant to round fruit shape (oo) with the heterozygote $(\mathrm{Oo})$ being oval shaped (Weetman, 1937). Poole and Grimball (1945) found the same inheritance pattern in 'Peerless' $x$ 'Baby Delight' and 'Northern Sweet' $\times$ 'Dove'.

The objectives of this experiment were to study the inheritance of exterior fruit traits of watermelon that had not been investigated before, including stripe width, stripe color, solid rind color, fruit shape, and blossom end shape (concave vs. convex). We were also able to confirm some of the known genes, such as $o$ for fruit shape (elongate vs. round), and $f$ for fruit surface furrowing.

\section{Materials and Methods}

Watermelon type-lines. A total of nine watermelon type-lines were used in crosses. For each family, seven generations were produced: parent $\mathrm{A}\left(\mathrm{P}_{\mathrm{a}}\right)$, parent $\mathrm{B}\left(\mathrm{P}_{\mathrm{b}}\right), \mathrm{F}_{1}$, $F_{1}$ reciprocal $\left(F_{1} '\right), F_{2}$, backcross to parent $A$ $\left(\mathrm{BC}_{1} \mathrm{P}_{\mathrm{a}}\right)$, and backcross to parent $\mathrm{B}\left(\mathrm{BC}_{1} \mathrm{P}_{\mathrm{b}}\right)$. Seeds of the lines used in these experiments were collected based on descriptions in the watermelon gene list (Wehner, 2012).

The type-lines used as parents were as follows: 'PDS 808' has medium-wide medium-dark green stripes with unclear margins on a light green background (Fig. 1); 'Red-N-Sweet' has narrow dark green stripes with clear margins on a light green background, and round fruit with concave blossom ends (Fig. 2); 'Crimson Sweet' has medium-wide medium-green stripes with unclear margins on a light green background, round fruit with thick rind, and smooth fruit surface (Fig. 3); 'Allsweet' has wide, medium-green stripes with unclear margins on a light green background, convex blossom end, elongate fruits, and smooth fruit surface (Fig. 4); 'Black Diamond' has solid dark rind, concave blossom end, and furrowed fruit surface (Fig. 5); 'Tendersweet Orange Flesh' has wide, medium-green stripes with unclear margins on a light green background, and oblong fruit (Fig. 6); 'Charleston Gray' has gray rind (light green with reticulations), convex blossom end, elongate fruit shape, and smooth fruit surface (Fig. 7); 'King\&Queen' has light green rind with inconspicuous light green stripes (solid light green), and round fruit (Fig. 8); 'Peacock Shipper' has solid medium dark green, concave blossom end,

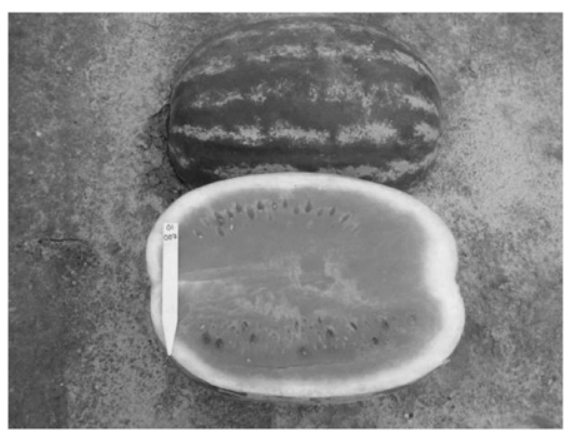

Fig. 1. A fruit of 'PDS 808 ' has rose flesh color, medium width, and medium-green stripes with unclear margins on a light green background.

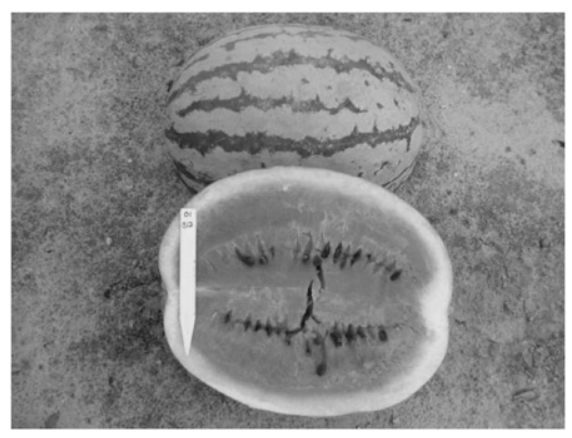

Fig. 2. A fruit of 'Red-N-Sweet' has scarlet flesh color, narrow width dark green stripes with clear margins on a light green background, long and dotted seeds, a round fruit shape, and concave blossom end. oblong fruit shape, and furrowed fruit surface (Fig. 9).

Fruit stripe width. Four families were developed by crossing parents having different stripe widths: 1) 'Crimson Sweet' (medium stripe) $\times$ 'Red-N-Sweet' (narrow stripe); 2) 'PDS 808' (medium stripe) $\times$ 'Red-N-Sweet' (narrow stripe); 3) 'Allsweet' (wide stripe) $\times$ 'Red-N-Sweet' (narrow stripe); and 4) 'Tendersweet Orange Flesh' (wide stripe) $\times$ 'Red-N-Sweet' (narrow stripe). Seven families were developed by crossing a parent having striped rind with a parent having solid color rind: 1) 'Red-NSweet' (narrow stripe) $\times$ 'King\&Queen' (solid light green); 2) 'Red-N-Sweet' (narrow stripe) $\times$ 'Charleston Gray' (gray); 3 ) 'Crimson Sweet' (medium stripe) $\times$ 'Peacock Shipper' (solid medium green); 4) 'Red-NSweet' (narrow stripe) $\times$ 'Black Diamond' (solid dark green); 5) 'Crimson Sweet' (medium stripe) $\times$ 'King\&Queen' (solid light green); 6) 'Allsweet' (wide stripe) $\times$ 'King\&Queen' (solid light green); and 7) 'Allsweet' (wide stripe) $\times$ 'Black Diamond' (solid dark green). Three families were developed by crossing two solid color parents: 1) 'Peacock Shipper' (solid medium green) $\times$ 'Charleston Gray' (gray); 2) 'King\&Queen' (solid light green) $\times$ 'Peacock Shipper' (solid medium green); and 3) 'Black Diamond' (solid light green) $\times$ 'Charleston Gray' (gray) (Table 1; Fig. 10).

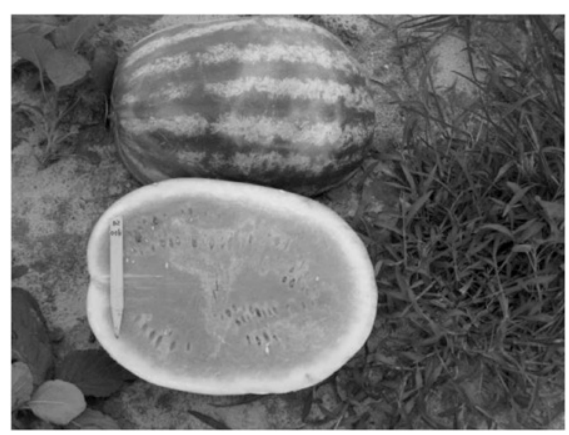

Fig. 3. A fruit of 'Crimson Sweet' has coral red flesh color, medium width medium-green stripes with unclear margins on a light green background, medium length seeds, a round fruit shape, thick rind, and smooth fruit surface.

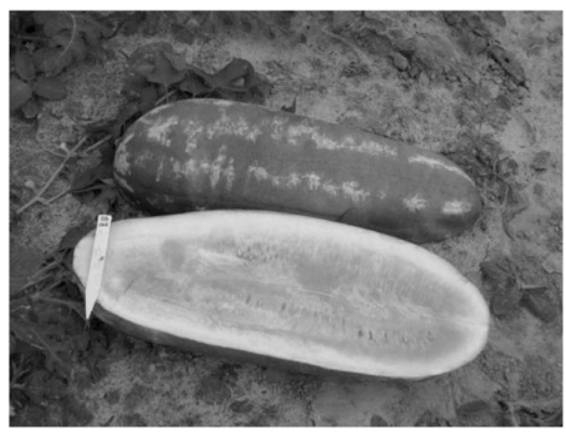

Fig. 4. A fruit of 'Allsweet' has coral red flesh color, wide medium-green stripes with unclear margins on a light green background, a convex blossom end, an elongate fruit shape, and a smooth fruit surface. 


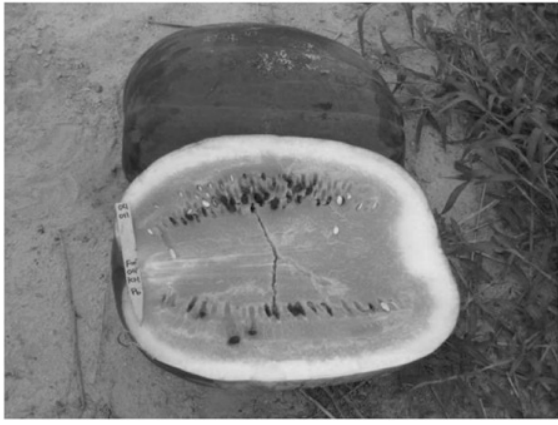

Fig. 5. A fruit of 'Black Diamond' has coral red flesh color, solid dark rind, a concave blossom end, and a furrowed fruit surface.

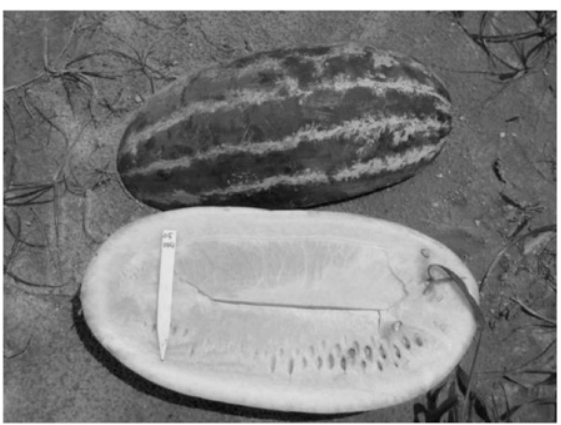

Fig. 6. A fruit of 'Tendersweet Orange Flesh' has orange flesh, wide medium-green stripes with unclear margins on a light green background, rimmed tan seeds, oblong fruit shape, and some hollow heart.

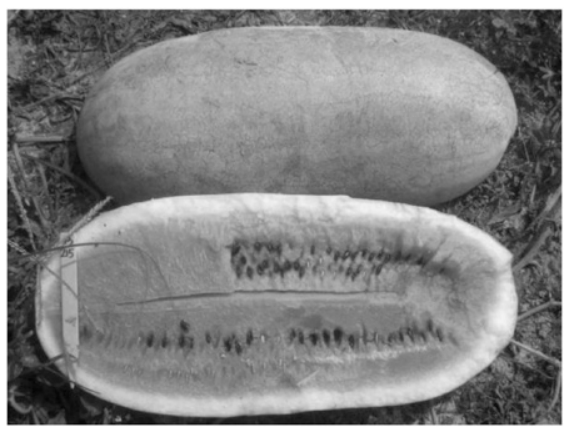

Fig. 7. A fruit of 'Charleston Gray' has coral flesh, gray (light green with reticulations) rind, long seeds, convex blossom end, an elongate fruit shape, a smooth fruit surface, and some hollow heart.

Fruit stripe margin and color. We observed two types of stripe margins in our experiments: one type had clear margins with well-defined boundaries separating the stripe from the background; the other had blurred margins and the stripe boundaries not well defined (Fig. 11). The stripe margin trait was measured in four families, 'PDS 808' (blurred) $\times$ 'Red-N-Sweet' (clear), 'Crimson Sweet' (blurred) $\times$ 'Red-N-Sweet' (clear), 'Allsweet' (blurred) $\times$ 'Red-N-Sweet' (clear), and 'Tendersweet Orange Flesh' (blurred) $\times$ 'Red-N-Sweet' (clear).

Fruit shape. Five families were developed to evaluate the inheritance of oblong, round, and elongate fruit shapes. We also observed

A

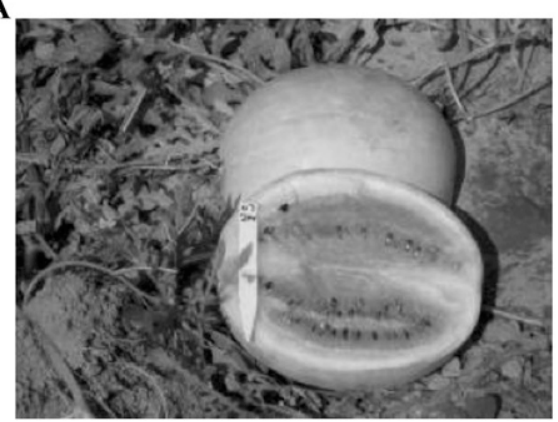

B

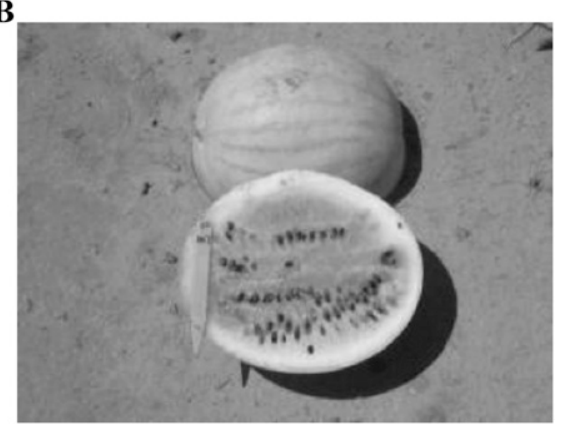

Fig. 8. Two fruit of 'King\&Queen' have coral flesh, solid light green (or light green stripe on a light green fruit) rind, medium long seeds, and round fruit shape.

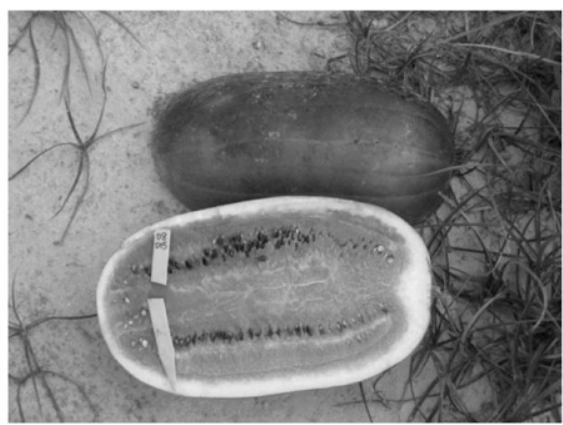

Fig. 9. A fruit of 'Peacock Shipper' has coral red flesh, solid medium-dark green rind, medium length black seeds, concave blossom end, oblong fruit shape, and a furrowed fruit surface.

oval shape, making a continuum from round to oval to oblong to elongate. Therefore, oval was intermediate to round and oblong, and oblong was intermediate to oval and elongate. These families were: 1) 'Red-N-Sweet' (round) $\times$ 'Tendersweet Orange Flesh' (oblong), 2) 'Crimson Sweet' (round) $\times$ 'Peacock Shipper' (oblong), 3) 'Peacock Shipper' (oblong) $\times$ 'Charleston Gray' (elongate), 4) 'King\&Queen' (round) $\times$ 'Peacock Shipper' (oblong).

Cultural practices. Seeds of the seven generations for each family were sown in 72-cell polyethylene flats in the greenhouses at North Carolina State University. The soilless growing medium used for seed germination was composed of Canadian sphagnum peatmoss, perlite, vermiculite, and processed pine bark. The flats were moistened to capacity after seeding and kept in a greenhouse at $25-30{ }^{\circ} \mathrm{C}$ until emergence of seedlings. The transplants were moved to coldframes for acclimation 1 week before transplanting. The seedlings were transplanted by hand at the two-true-leaf stage. Missing or damaged transplants were replaced one week after the initial transplanting.

In the field, raised beds had drip irrigation tubes under black polyethylene mulch. The experiment was conducted using horticultural practices recommended by the North Carolina Extension Service (Sanders, 2004). To keep plants separate for data collection, each was trained weekly into a spiral shape by turning all the vines in a clockwise circle around the crown until fruit set. The vine training allowed tracing of the fruit to the plant that produced it.

One mature fruit was harvested from each plant. Fruits were determined to be ripe by looking for a dried tendril nearest the fruit, a light-colored ground spot, dull rather than shiny fruit surface, and a dull sound of the fruit when thumped (Maynard, 2001). Fruit traits were evaluated in the field.

Experiment design and data analysis. Field experiments were performed in the summer of 2008 at two North Carolina locations: Cunningham Research Station in Kinston and Horticultural Crops Research Station in Clinton. The experiment was run in two sets (two locations) as a precautionary measure in case of adverse weather, environmental stress, or disease epidemics that might damage a location. For each location, there were 10 plants of $\mathrm{P}_{\mathrm{a}} \mathrm{S}_{1}$, 10 of $\mathrm{P}_{\mathrm{b}} \mathrm{S}_{1}, 10$ of $\mathrm{F}_{1}, 10$ of $\mathrm{F}_{1}, 30$ of $\mathrm{BC}_{1} \mathrm{P}_{\mathrm{a}}, 30$ of $\mathrm{BC}_{1} \mathrm{P}_{\mathrm{b}}$, and 100 of $\mathrm{F}_{2}$. At Kinston, each field was 0.4 ha with six rows $85-\mathrm{m}$ long and each family occupied three rows. At Clinton, each field was 0.4 ha with eight rows $60-\mathrm{m}$ long and each family occupied four rows. The fields had raised and shaped beds (rows) on $3.1 \mathrm{~m}$ centers with single hills $1.2 \mathrm{~m}$ apart.

The data were analyzed by location and family for each tested trait and then pooled if homogeneous. Segregation analysis and goodness-of-fit tests were performed based on $\chi^{2}$ testing of the expected segregation ratios for a single gene, using the SASSTAT statistical package (SAS Institute, Cary, NC) and the SASGene 1.2 program (Liu et al., 1997). The calculations were done manually for the families involving a heterozygote with a third phenotype (incomplete dominance) other than the two parents, or when two gene loci were involved. All $\chi^{2}$ tests were performed with a $95 \%$ confidence level. For the generations $\mathrm{F}_{1}$ and $\mathrm{F}_{1}$, when both had the same phenotype, $F_{1}$ and $F_{1}$ ' were pooled as a single generation. When the $F_{1}$ differed from the reciprocal, they were treated as separate generations. Gene nomenclature rules for the Cucurbitaceae family (Cucurbit Gene List Committee, 1982) were applied for naming the proposed new genes.

\section{Results and Discussion}

Fruit stripe width. In the family 'Crimson Sweet' (medium stripe) $\times$ 'Red-N-Sweet' 


\begin{tabular}{|c|c|}
\hline Family & Trait phenotype \\
\hline \multicolumn{2}{|l|}{ Study of new genes } \\
\hline \multicolumn{2}{|l|}{ Stripe pattern } \\
\hline 'Crimson Sweet' $\times$ 'Red-N-Sweet' & Medium stripe vs. narrow stripe (Table 2) \\
\hline 'PDS 808 ' $\times$ 'Red-N-Sweet' & Medium stripe vs. narrow stripe (no table) \\
\hline 'Allsweet' × 'Red-N-Sweet' & Wide stripe vs. narrow stripe (Table 3 ) \\
\hline 'Tendersweet OF' $\times$ 'Red-N-Sweet' & Wide stripe vs. narrow stripe (Table 3) \\
\hline 'Red-N-Sweet' × 'King\&Queen' & Narrow stripe vs. solid light green (Table \\
\hline 'Red-N-Sweet' × 'Charleston Gray' & Narrow stripe vs. gray (Table 5) \\
\hline 'Peacock Shipper' $\times$ 'Crimson Sweet' & Solid medium green vs. medium stripe ( $\mathrm{T}$ \\
\hline 'Black Diamond' $\times$ 'Red-N-Sweet' & Solid dark green vs. narrow stripe (no tabl \\
\hline 'Crimson Sweet' × ‘King\&Queen’ & Medium stripe vs. solid light green (Table \\
\hline 'Allsweet' $\times$ 'King\&Queen' & Wide stripe vs. solid light green (no table) \\
\hline 'Black Diamond' $\times$ 'Allsweet' & Solid dark green vs. wide stripe (Table 8) \\
\hline 'Peacock Shipper' $\times$ 'Charleston Gray' & Solid medium green vs. gray (Table 9) \\
\hline 'King\&Queen' $\times$ 'Peacock Shipper' & Solid medium green vs. solid light (no tab \\
\hline 'Black Diamond' $\times$ 'Charleston Gray' & Solid dark green vs. gray (no table) \\
\hline \multicolumn{2}{|l|}{ Stripe margin (clear, blurred) } \\
\hline 'Crimson Sweet' $\times$ 'Red-N-Sweet' & Blurred stripe margin vs. clear (Table 10) \\
\hline 'Allsweet' × 'Red-N-Sweet' & Blurred stripe margin vs. clear (Table 10) \\
\hline 'Tendersweet OF' $\times$ 'Red-N-Sweet' & Blurred stripe margin vs. clear (Table 10) \\
\hline 'PDS 808 ' $\times$ 'Red-N-Sweet' & Blurred stripe margin vs. clear (no table) \\
\hline \multicolumn{2}{|l|}{ Fruit shape } \\
\hline 'Red-N-Sweet' × 'Tendersweet OF' & Round vs. oblong (Table 11) \\
\hline 'Crimson Sweet' $\times$ 'Peacock Shipper' & Round vs. oblong (Table 11) \\
\hline 'Charleston Gray' × 'Peacock Shipper' & Elongate vs. oblong (Table 12) \\
\hline 'King\&Queen' $\times$ 'Peacock Shipper' & Round vs. oblong (no table) \\
\hline 'Crimson Sweet' $\times$ 'King\&Queen' & Round vs. round (no table) \\
\hline 'Red-N-Sweet' × 'King\&Queen' & Round vs. round (no table) \\
\hline \multicolumn{2}{|l|}{ Stripe color } \\
\hline 'Crimson Sweet' $\times$ 'Red-N-Sweet' & Medium green vs. dark green (no table) \\
\hline 'Allsweet' $\times$ 'Red-N-Sweet' & Medium green vs. dark green (no table) \\
\hline 'Crimson Sweet' $\times$ 'King\&Queen' & Medium green vs. light green (no table) \\
\hline 'Allsweet' $\times$ 'King\&Queen' & Medium green vs. light green (no table) \\
\hline \multicolumn{2}{|l|}{ Blossom end } \\
\hline 'Red-N-Sweet' × 'Allsweet' & Concave vs. convex (no table) \\
\hline 'Black Diamond' × 'Allsweet' & Concave vs. convex (no table) \\
\hline 'Peacock Shipper' $\times$ 'Charleston Gray' & Concave vs. convex (no table) \\
\hline \multicolumn{2}{|l|}{ Verification of known genes } \\
\hline \multicolumn{2}{|l|}{ Fruit shape } \\
\hline 'Allsweet' $\times$ 'Red-N-Sweet' & Elongate vs. round (Table 13) \\
\hline 'Charleston Gray' × 'Red-N-Sweet' & Elongate vs. round (Table 13) \\
\hline 'Allsweet' $\times$ 'Black Diamond' & Elongate vs. round (Table 13) \\
\hline 'Charleston Gray' $\times$ 'Black Diamond' & Elongate vs. round (Table 13) \\
\hline 'Allsweet' $\times$ 'King\&Queen' & Elongate vs. round (Table 13) \\
\hline \multicolumn{2}{|l|}{ Furrowed } \\
\hline 'Charleston Gray' $\times$ 'Peacock Shipper' & Smooth vs. furrowed (no table) \\
\hline 'Crimson Sweet' $\times$ 'Peacock Shipper' & Smooth vs. furrowed (no table) \\
\hline 'Allsweet' $\times$ 'Black Diamond' & Smooth vs. furrowed (no table) \\
\hline
\end{tabular}

(narrow stripe), all $\mathrm{F}_{1}$ fruit had medium stripes, which indicates the medium stripe is dominant over narrow stripe. $F_{2}$ progenies segregated into medium stripe and narrow stripe with a ratio $3: 1 . \mathrm{BC}_{1} \mathrm{P}_{\mathrm{b}}$ segregated into medium stripe and narrow stripe with a ratio $1: 1$, and all $\mathrm{BC}_{1} \mathrm{P}_{\mathrm{a}}$ were medium stripe (Table 2). Thus, medium stripe was controlled by a single gene dominant over narrow stripe. However, in the family of 'PDS 808' (medium stripe) $\times$ 'Red-N-Sweet' (narrow stripe), no Mendelian pattern of inheritance was observed. All $\mathrm{F}_{1}, \mathrm{~F}_{1}, \mathrm{BC}_{1} \mathrm{P}_{\mathrm{a}}$, $\mathrm{BC}_{1} \mathrm{P}_{\mathrm{b}}$, and $\mathrm{F}_{2}$ fruit had stripe width similar to 'Red-N-Sweet'.

In the families with a wide striped parent crossed with a narrow striped parent, 'Allsweet' (wide stripe) $\times$ 'Red-N-Sweet' (narrow stripe) and 'Tendersweet Orange Flesh' (wide stripe) $\times$ 'Red-N-Sweet' (narrow stripe), all $\mathrm{F}_{1}$ fruit were wide striped, indicating that wide stripe is dominant over narrow stripe. The $F_{2}$ segregated 3 wide stripe: 1 narrow stripe and $\mathrm{BC}_{1} \mathrm{P}_{\mathrm{b}}$ segregated 1 wide stripe: 1 narrow stripe. The $\mathrm{BC}_{1} \mathrm{P}_{\mathrm{a}}$ were all wide stripe (Table 3 ). The $F_{1}$ and $F_{2}$ showed that wide stripe from 'Allsweet' is a single gene dominant over the narrow stripe of 'Red-N-Sweet'.

Two families had a wide striped parent crossed with a solid green parent, 'Red-NSweet' (narrow stripe) $\times$ 'King\&Queen' (light green rind with inconspicuous light narrow stripes, appearing solid light green) (Fig. 10) and 'Red-N-Sweet' (narrow stripe) $\times$ 'Charleston Gray' (gray) (Table 1). Although 'King\&Queen' has light green stripes, the rind pattern can be considered solid light green, since the stripes are inconspicuous. In the first family, all $F_{1}$ fruit had narrow stripes. That indicates narrow stripe was dominant over solid light green (Table 4). The $F_{2}$ segregated 3 narrow stripe: 1 solid light green, indicating that the narrow stripe of 'Red-N-Sweet' is a single gene that is dominant over solid light green in 'King\&Queen'. The $\mathrm{BC}_{1} \mathrm{P}_{\mathrm{a}}$ were all narrow stripe, and the $\mathrm{BC}_{1} \mathrm{P}_{\mathrm{b}}$ had 1 narrow stripe: 1 solid light green, confirming that inheritance pattern.

In the family 'Red-N-Sweet' (narrow stripe) $\times$ 'Charleston Gray' (light green with reticulations, called gray), all $\mathrm{F}_{1}$ had narrow stripe, indicating dominance over gray. The segregation ratios in the $\mathrm{F}_{2}$ ( 3 narrow stripe: 1 light green) and $\mathrm{BC}_{1} \mathrm{P}_{\mathrm{b}}$ (1 narrow stripe: 1 light green) further confirmed that narrow stripe of 'Red-N-Sweet' is controlled by a single dominant gene (Table 5). This is a similar pattern to 'Red-N-Sweet' (narrow stripe) $\times$ 'King\&Queen' (solid light green).

In the family with a striped parent crossed with a solid parent, 'Crimson Sweet' (medium-wide stripe) $\times$ 'Peacock Shipper' (solid medium green), the $F_{1}$ fruit had solid medium green rind and the $F_{2}$ segregated 3 solid medium green: 1 medium stripe. The 


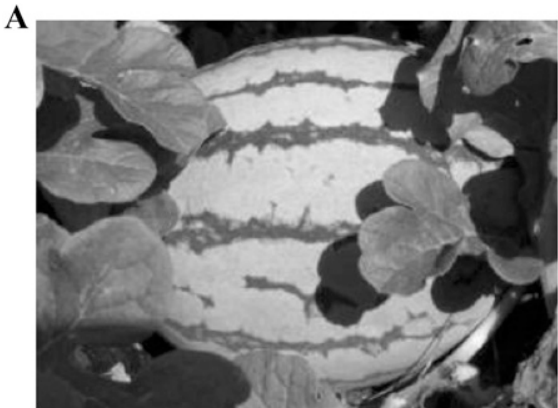

B

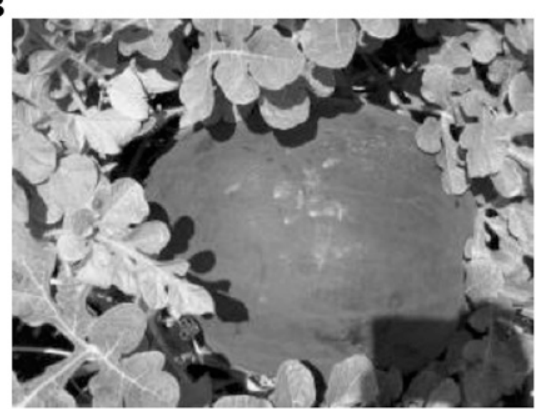

$\mathrm{C}$

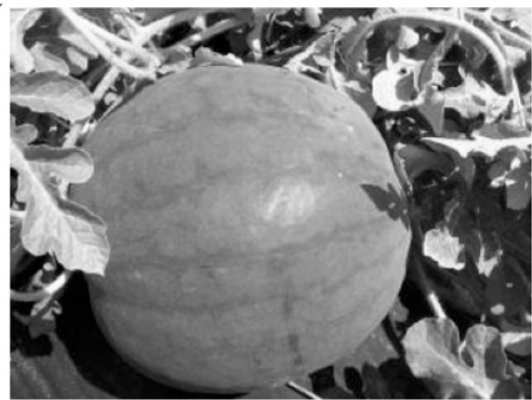

Fig. 10. (A) Narrow stripes on a 'Red-N-Sweet' fruit (B) Solid dark-green rind on a 'Black Diamond' fruit. (C) An F fruit of 'Red-N-Sweet' $\times$ 'Black Diamond' has intermediate medium green rind with inconspicuous narrow stripes.

$\mathrm{BC}_{1} \mathrm{P}_{\mathrm{a}}$ had 1 solid medium green: 1 medium stripe fruit and the $\mathrm{BC}_{1} \mathrm{P}_{\mathrm{b}}$ were all solid medium green (Table 6). Thus, solid medium green rind of 'Peacock Shipper' is a single gene, dominant over medium stripe of 'Crimson Sweet'.

For the other four families involving a striped parent and a solid green parent, the results were more complicated. Intermediate phenotypes were often present in the $F_{1}$ and the green shades of $F_{2}$ progeny often acted like a quantitative trait making classification difficult. These four families were 'Red-NSweet' (narrow stripe) $\times$ 'Black Diamond' (solid dark green), 'Crimson Sweet' (medium stripe) $\times$ 'King\&Queen' (solid light green), 'Allsweet' (wide stripe) $\times$ 'King\&Queen' (solid light green), and 'Allsweet' (wide stripe) $\times$ 'Black Diamond' (solid dark green) (Table 1). In the family 'Red-N-Sweet' (narrow stripe) $\times$ 'Black Diamond' (solid dark green), all $F_{1}$ fruit had an intermediate phenotype. The color of the $F_{1}$ was lighter than 'Black Diamond' and darker than the light green background of 'Red-N-Sweet'. The fruit of the $F_{1}$ had inconspicuous stripes that were difficult to see on some individuals
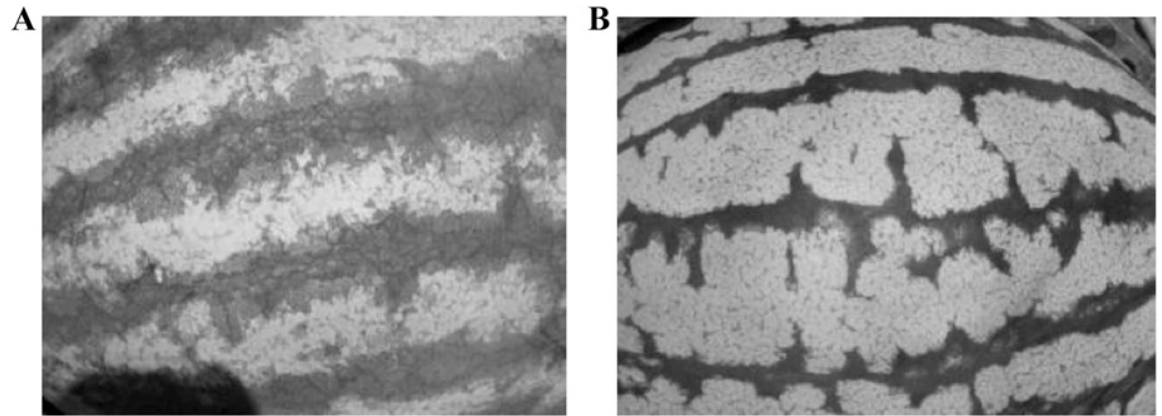

Fig. 11. Two different stripe margin patterns: blurred (left) and clear (right).

Table 2. Single locus goodness-of-fit-test for stripe width in watermelon in family 'Crimson Sweet' (medium stripe) $\times$ 'Red-N-Sweet' (narrow stripe) in trials at Kinston and Clinton, NC.

\begin{tabular}{lcccccccc}
\hline Generation & $\begin{array}{c}\text { Total } \\
\text { no. }^{\mathrm{z}}\end{array}$ & $\begin{array}{c}\text { Medium } \\
\text { stripe }^{\mathrm{y}}\end{array}$ & $\begin{array}{c}\text { Narrow } \\
\text { stripe }^{\mathrm{x}}\end{array}$ & $\begin{array}{c}\text { No. } \\
\text { missing }\end{array}$ & $\begin{array}{c}\text { Expected } \\
\text { ratio }\end{array}$ & $\begin{array}{c}\text { Chi } \\
\text { square }\end{array}$ & df & Prob. \\
\hline $\mathrm{P}_{\mathrm{a}} \mathrm{S}_{1}$ & 20 & 15 & 0 & 5 & & & & \\
$\mathrm{P}_{\mathrm{b}} \mathrm{S}_{1}$ & 20 & 0 & 19 & 1 & & & & \\
$\mathrm{~F}_{1}$ & 40 & 34 & 0 & 6 & & & & \\
$\mathrm{~F}_{2}$ & 200 & 105 & 45 & 50 & $3: 1$ & 2.00 & 1 & $0.15^{*}$ \\
$\mathrm{BC}_{1} \mathrm{P}_{\mathrm{a}}$ & 60 & 43 & 1 & 16 & $1: 0$ & 0.02 & 1 & $0.88^{*}$ \\
$\mathrm{BC}_{1} \mathrm{P}_{\mathrm{b}}$ & 60 & 24 & 20 & 16 & $1: 1$ & 0.36 & 1 & $0.54^{*}$ \\
\hline
\end{tabular}

${ }^{\mathrm{z}}$ Data were pooled over the two locations.

${ }^{\mathrm{y}}$ Medium stripe was dominant and $\mathrm{P}_{\mathrm{a}}$ was the carrier.

${ }^{\mathrm{x}}$ Narrow stripe was recessive and $\mathrm{P}_{\mathrm{b}}$ was the carrier.

* Significant at the $0.05 P$ level.

Table 3. Single locus goodness-of-fit-test for stripe width in watermelon for crossings involving wide stripe $\times$ narrow stripe in trials at Kinston and Clinton, NC.

\begin{tabular}{|c|c|c|c|c|c|c|c|c|}
\hline Generation & $\begin{array}{c}\text { Total } \\
\text { no. }{ }^{z}\end{array}$ & $\begin{array}{l}\text { Wide } \\
\text { stripe }^{y}\end{array}$ & $\begin{array}{c}\text { Narrow } \\
\text { stripe }^{\mathrm{x}}\end{array}$ & $\begin{array}{c}\text { No. } \\
\text { missing }\end{array}$ & $\begin{array}{c}\text { Expected } \\
\text { ratio }\end{array}$ & $\begin{array}{c}\text { Chi } \\
\text { Square }\end{array}$ & df & Prob. \\
\hline \multicolumn{9}{|c|}{ 'Allsweet' (wide) × 'Red-N-Sweet' (narrow) } \\
\hline $\mathrm{P}_{\mathrm{a}} \mathrm{S}_{1}$ & 20 & 8 & 0 & 12 & & & & \\
\hline $\mathrm{P}_{\mathrm{b}} \mathrm{S}_{1}$ & 20 & 0 & 10 & 10 & & & & \\
\hline $\mathrm{F}_{1}$ & 40 & 31 & 1 & 8 & & & & \\
\hline $\mathrm{F}_{2}$ & 200 & 98 & 39 & 63 & $3: 1$ & 0.88 & 1 & $0.34^{*}$ \\
\hline $\mathrm{BC}_{1} \mathrm{P}_{\mathrm{a}}$ & 60 & 42 & 3 & 15 & $1: 0$ & 0.20 & 1 & $0.65^{*}$ \\
\hline $\mathrm{BC}_{1} \mathrm{P}_{\mathrm{b}}$ & 60 & 15 & 15 & 30 & $1: 1$ & 0.00 & 1 & $1.00 *$ \\
\hline \multicolumn{9}{|c|}{ 'Tendersweet Orange Flesh' (wide) $\times$ 'Red-N-Sweet' (narrow) } \\
\hline $\mathrm{P}_{\mathrm{a}} \mathrm{S}_{1}$ & 20 & 20 & 0 & 0 & & & & \\
\hline $\mathrm{P}_{\mathrm{b}} \mathrm{S}_{1}$ & 20 & 0 & 13 & 7 & & & & \\
\hline $\mathrm{F}_{1}$ & 40 & 34 & 0 & 6 & & & & \\
\hline $\mathrm{F}_{2}$ & 200 & 125 & 34 & 41 & $3: 1$ & 1.11 & 1 & $0.29 *$ \\
\hline $\mathrm{BC}_{1} \mathrm{P}_{\mathrm{a}}$ & 60 & 54 & 0 & 6 & $1: 0$ & 0.00 & 1 & $1.00 *$ \\
\hline $\mathrm{BC}_{1} \mathrm{P}_{\mathrm{b}}$ & 60 & 27 & 29 & 4 & $1: 1$ & 0.07 & 1 & $0.78^{*}$ \\
\hline \multicolumn{9}{|l|}{ Pooled } \\
\hline $\mathrm{P}_{\mathrm{a}} \mathrm{S}_{1}$ & 40 & 28 & 0 & 12 & & & & \\
\hline $\mathrm{P}_{\mathrm{b}} \mathrm{S}_{1}$ & 40 & 0 & 23 & 17 & & & & \\
\hline $\mathrm{F}_{1}$ & 80 & 65 & 1 & 14 & & & & \\
\hline $\mathrm{F}_{2}$ & 400 & 223 & 73 & 104 & $3: 1$ & 0.02 & 1 & $0.89 *$ \\
\hline $\mathrm{BC}_{1} \mathrm{P}_{\mathrm{a}}$ & 120 & 96 & 3 & 21 & $1: 0$ & 0.09 & 1 & $0.76^{*}$ \\
\hline $\mathrm{BC}_{1} \mathrm{P}_{\mathrm{b}}$ & 120 & 42 & 44 & 34 & $1: 1$ & 0.05 & 1 & $0.82^{*}$ \\
\hline
\end{tabular}

${ }^{\mathrm{z}}$ Data were pooled over the two locations.

${ }^{y}$ Wide stripe was dominant and $\mathrm{P}_{\mathrm{a}}$ was the carrier.

${ }^{\mathrm{x}}$ Narrow stripe was recessive and $\mathrm{P}_{\mathrm{b}}$ was the carrier. *Significant at the $0.05 P$ level.

(Fig. 10). The $\mathrm{F}_{2}$ segregated into three classes, the $\mathrm{P}_{\mathrm{a}}$ phenotype, the $\mathrm{P}_{\mathrm{b}}$ phenotype, and the intermediate $\mathrm{F}_{1}$ phenotype, and the green color of the $\mathrm{F}_{2}$ (disregarding the stripes) was difficult to classify. The goodness-of-fit tests for the $\mathrm{F}_{2}, \mathrm{BC}_{1} \mathrm{P}_{\mathrm{a}}$, and $\mathrm{BC}_{1} \mathrm{P}_{\mathrm{b}}$ data were not significant, probably because of misclassification due to the inconspicuous stripes of the intermediate phenotype. The intermediate $F_{1}$ phenotype also indicated that the color shade and stripes were controlled by different gene loci. Porter (1937) investigated two similar families between solid dark green cultivars and striped cultivars, California Klondike (solid dark green) $\times$ Golden Honey (striped) and Golden Honey (striped) $\times$ Angeleno Black Seeded (solid dark green). In both of the $F_{1}$, fruit were intermediate with faint stripes different from both parents, and the $F_{2}$ had a 1:2:1 segregation ratio. However, it is unclear how that compares with our findings since the $F_{2}$ and backcross data were not presented (Porter, 1937).

In the family 'Crimson Sweet' (medium stripe $) \times$ 'King\&Queen' (solid light green), the $F_{1}$ fruit had medium stripes that were 
narrower than the striped parent 'Crimson Sweet'. The $\mathrm{F}_{2}$ and backcross had fruit with various stripe widths. Disregarding the stripe width, there were two phenotypes in $F_{2}$, striped and solid, with a ratio close to $3: 1$ (Table 7). All $\mathrm{BC}_{1} \mathrm{P}_{\mathrm{a}}$ fruit were striped. Unfortunately, the $\mathrm{BC}_{1} \mathrm{P}_{\mathrm{b}}$ fruit also were all striped, although we expected a ratio of 1 striped: 1 light green fruit. The $\mathrm{F}_{2}$ progenies showed that medium stripe is a single gene, dominant over solid light green, but the $\mathrm{BC}_{1} \mathrm{P}_{\mathrm{b}}$ failed to verify it. Further study is needed.

In the family 'Allsweet' (wide stripe) $\times$ 'King\&Queen' (solid light green), all $\mathrm{F}_{1}$ were medium striped. Similar to 'Crimson Sweet' (medium stripe) $\times$ 'King\&Queen' (solid light green), the $F_{2}$ progeny was a mixture of various green shades and stripe widths. The stripes are blended into the background color and were difficult to classify. All $\mathrm{BC}_{1} \mathrm{P}_{\mathrm{a}}$ were wide stripe and $\mathrm{BC}_{1} \mathrm{P}_{\mathrm{b}}$ were similar to $\mathrm{F}_{2}$ progenies. No clear Mendelian inheritance was identified in this family.

In the family 'Allsweet' (wide stripe) $\times$ 'Black Diamond' (solid dark green), the $F_{1}$ fruit had intermediate, solid medium green rind. The $\mathrm{F}_{2}$ segregated into striped and solidcolored fruits with different shades of green. If the shades of green were disregarded and the phenotypes classified into stripe and solid green, then the data fit the pattern of a single gene, with solid dark green dominant to wide stripe (Table 8), and confirmed by the $\mathrm{BC}_{1} \mathrm{P}_{\mathrm{a}}$ and $\mathrm{BC}_{1} \mathrm{P}_{\mathrm{b}}$. It appears that some wide stripe fruit were misclassified as solid dark green, indicating that stripes were difficult to distinguish from background color.

Three families were made using solid green parents, 'Peacock Shipper' (solid medium green) $\times$ 'Charleston Gray' (gray), 'King\&Queen' (solid light green) $\times$ 'Peacock Shipper' (solid medium green), and 'Black Diamond' (solid dark green) $\times$ 'Charleston Gray' (gray) (Table 1). For 'Peacock Shipper' (solid medium green) $\times$ 'Charleston Gray' (gray), the $\mathrm{F}_{1}$ fruit were solid medium green rind, indicating that solid medium green rind is dominant over light green rind. Both parents have reticulations on the rind, but the reticulation was ignored for this trait. The $F_{2}$ progeny segregated medium green, light green, and a medium light green color (between the light green of 'Charleston Gray' and the medium green of 'Peacock Shipper'). The segregation ratio was $3: 1$ when combining medium and medium light green fruit and comparing with light green (Table 9). The segregation ratios in the $\mathrm{F}_{2}$ and $\mathrm{BC}_{1} \mathrm{P}_{\mathrm{b}}$ suggest that the solid medium green rind of 'Peacock Shipper' is a single gene, dominant over the light green rind of 'Charleston Gray'.

Weetman (1937) conducted similar research on watermelon rind using two families, 'Long Iowa Belle' (medium dark green with a distinctive greenish-white mottling) $\times$ 'Japan 6' (light green; called gray) and 'Long Iowa Belle' $\times$ 'Japan 4' (light green; called gray). 'Long Iowa Belle' has medium dark green rind with a distinctive greenish-white

Table 4. Single locus goodness-of-fit-test for stripe in watermelon in family 'Red-N-Sweet' (narrow stripe) $\times$ 'King\&Queen' (solid light green) in trials at Kinston and Clinton, NC.

\begin{tabular}{lrccccccc}
\hline Generation & $\begin{array}{c}\text { Total } \\
\text { no. }^{\mathrm{z}}\end{array}$ & $\begin{array}{c}\text { Narrow } \\
\text { stripe }^{\mathrm{y}}\end{array}$ & $\begin{array}{c}\text { Solid light } \\
\text { green }^{\mathrm{x}}\end{array}$ & $\begin{array}{c}\text { No. } \\
\text { missing }\end{array}$ & $\begin{array}{c}\text { Expected } \\
\text { ratio }\end{array}$ & $\begin{array}{c}\text { Chi } \\
\text { square }\end{array}$ & df & Prob. \\
\hline $\mathrm{P}_{\mathrm{a}} \mathrm{S}_{1}$ & 20 & 17 & 0 & 3 & & & & \\
$\mathrm{P}_{\mathrm{b}} \mathrm{S}_{1}$ & 20 & 0 & 15 & 5 & & & & \\
$\mathrm{~F}_{1}$ & 40 & 33 & 0 & 7 & & & & \\
$\mathrm{~F}_{2}$ & 200 & 143 & 41 & 16 & $3: 1$ & 0.72 & 1 & $0.39^{*}$ \\
$\mathrm{BC}_{1} \mathrm{P}_{\mathrm{a}}$ & 60 & 42 & 1 & 17 & $1: 0$ & 0.02 & 1 & $0.87^{*}$ \\
$\mathrm{BC}_{1} \mathrm{P}_{\mathrm{b}}$ & 60 & 36 & 23 & 1 & $1: 1$ & 2.86 & 1 & $0.09^{*}$ \\
\hline
\end{tabular}

${ }^{2}$ Data were pooled over the two locations.

${ }^{y}$ Narrow stripe was dominant and $\mathrm{P}_{\mathrm{a}}$ was the carrier.

${ }^{\mathrm{x}}$ Solid light green was recessive and $\mathrm{P}_{\mathrm{b}}$ was the carrier.

*Significant at the $0.05 P$ level.

Table 5. Single locus goodness-of-fit-test for stripe width in watermelon in family 'Red-N-Sweet' (narrow stripe) $\times$ 'Charleston Gray' (gray) in trials at Kinston and Clinton, NC.

\begin{tabular}{|c|c|c|c|c|c|c|c|c|}
\hline Generation & $\begin{array}{c}\text { Total } \\
\text { no. }^{z}\end{array}$ & $\begin{array}{l}\text { Narrow } \\
\text { stripe }^{y}\end{array}$ & Gray $^{x}$ & $\begin{array}{c}\text { No. } \\
\text { missing }\end{array}$ & $\begin{array}{l}\text { Expected } \\
\text { ratio }\end{array}$ & $\begin{array}{c}\text { Chi } \\
\text { square }\end{array}$ & $\mathrm{df}$ & Prob. \\
\hline$\overline{\mathrm{P}_{\mathrm{a}} \mathrm{S}_{1}}$ & 20 & 19 & 0 & 1 & & & & \\
\hline $\mathrm{P}_{\mathrm{b}} \mathrm{S}_{1}$ & 20 & 0 & 8 & 12 & & & & \\
\hline $\mathrm{F}_{1}$ & 40 & 30 & 0 & 10 & & & & \\
\hline $\mathrm{F}_{2}$ & 200 & 128 & 39 & 33 & $3: 1$ & 0.24 & 1 & $0.62 *$ \\
\hline $\mathrm{BC}_{1} \mathrm{P}_{\mathrm{a}}$ & 60 & 54 & 0 & 6 & 1:0 & 0.00 & 1 & $1.00 *$ \\
\hline $\mathrm{BC}_{1} \mathrm{P}_{\mathrm{b}}$ & 60 & 26 & 30 & 4 & 1:1 & 0.29 & 1 & $0.59^{*}$ \\
\hline
\end{tabular}

${ }^{\mathrm{z}}$ Data were pooled over the two locations.

${ }^{y}$ Narrow stripe was dominant and $\mathrm{P}_{\mathrm{a}}$ was the carrier.

${ }^{\mathrm{x}}$ Gray was recessive and $\mathrm{P}_{\mathrm{b}}$ was the carrier.

* Significant at the $0.05 P$ level.

Table 6. Single locus goodness-of-fit-test for stripe width in watermelon in family 'Peacock Shipper' (solid medium green) $\times$ 'Crimson Sweet' (medium stripe) in trials at Kinston and Clinton, NC.

\begin{tabular}{lcccccccr}
\hline Generation & $\begin{array}{c}\text { Total } \\
\text { no. }^{\mathrm{z}}\end{array}$ & $\begin{array}{c}\text { Solid medium } \\
\text { green }^{\mathrm{y}}\end{array}$ & $\begin{array}{c}\text { Medium } \\
\text { stripe }^{\mathrm{x}}\end{array}$ & $\begin{array}{c}\text { No. } \\
\text { missing }\end{array}$ & $\begin{array}{c}\text { Expected } \\
\text { ratio }\end{array}$ & $\begin{array}{c}\text { Chi } \\
\text { square }\end{array}$ & df & Prob. \\
\hline $\mathrm{P}_{\mathrm{a}} \mathrm{S}_{1}$ & 20 & 20 & 0 & 0 & & & & \\
$\mathrm{P}_{\mathrm{b}} \mathrm{S}_{1}$ & 20 & 0 & 18 & 2 & & & & \\
$\mathrm{~F}_{1}$ & 40 & 39 & 0 & 1 & & & & \\
$\mathrm{~F}_{2}$ & 200 & 138 & 36 & 26 & $3: 1$ & 1.72 & 1 & $0.18^{*}$ \\
$\mathrm{BC}_{1} \mathrm{P}_{\mathrm{a}}$ & 60 & 56 & 0 & 4 & $1: 0$ & 0.00 & 1 & $1.00^{*}$ \\
$\mathrm{BC}_{1} \mathrm{P}_{\mathrm{b}}$ & 60 & 27 & 29 & 4 & $1: 1$ & 0.07 & 1 & $0.78^{*}$ \\
\hline
\end{tabular}

${ }^{\mathrm{x}}$ Data were pooled over the two locations.

${ }^{\mathrm{y}}$ Solid medium green was dominant and $\mathrm{P}_{\mathrm{a}}$ was the carrier.

${ }^{\mathrm{x}}$ Medium stripe was recessive and $\mathrm{P}_{\mathrm{b}}$ was the carrier.

* Significant at the $0.05 P$ level.

Table 7. Single locus goodness-of-fit-test for stripe width in watermelon in family 'Crimson Sweet' (medium stripe) $\times$ 'King\&Queen' (solid light green) in trials at Kinston and Clinton, NC.

\begin{tabular}{lcccccccr}
\hline Generation & $\begin{array}{c}\text { Total } \\
\text { no. }^{z}\end{array}$ & $\begin{array}{c}\text { Medium } \\
\text { stripe }^{\mathrm{y}}\end{array}$ & $\begin{array}{c}\text { Solid light } \\
\text { green }^{\mathrm{x}}\end{array}$ & $\begin{array}{c}\text { No. } \\
\text { missing }\end{array}$ & $\begin{array}{c}\text { Expected } \\
\text { ratio }\end{array}$ & $\begin{array}{c}\text { Chi } \\
\text { square }\end{array}$ & df & Prob. \\
\hline $\mathrm{P}_{\mathrm{a}} \mathrm{S}_{1}$ & 20 & 17 & 0 & 3 & & & & \\
$\mathrm{P}_{\mathrm{b}} \mathrm{S}_{1}$ & 20 & 0 & 16 & 4 & & & & \\
$\mathrm{~F}_{1}$ & 40 & 33 & 0 & 7 & & & & \\
$\mathrm{~F}_{2}$ & 200 & 112 & 42 & 46 & $3: 1$ & 0.42 & 1 & $0.51^{*}$ \\
$\mathrm{BC}_{1} \mathrm{P}_{\mathrm{a}}$ & 60 & 54 & 0 & 6 & $1: 0$ & 0.00 & 1 & $1.00^{*}$ \\
$\mathrm{BC}_{1} \mathrm{P}_{\mathrm{b}}$ & 60 & 55 & 0 & 5 & $1: 1$ & 55.00 & 1 & 0.000 \\
\hline
\end{tabular}

${ }^{\mathrm{z}}$ Data were pooled over the two locations.

${ }^{\mathrm{y}}$ Medium stripe was dominant and $\mathrm{P}_{\mathrm{a}}$ was the carrier.

${ }^{\mathrm{x}}$ Solid light green was recessive and $\mathrm{P}_{\mathrm{b}}$ was the carrier.

* Significant at the $0.05 P$ level.

mottling, similar to 'Peacock Shipper' if the modifying pattern is disregarded. In Weetman's research, the $F_{1}$ was medium dark green and the $F_{2}$ progeny segregated into medium dark, light green, and medium light green. He observed a 3:1 ratio when light and medium light green fruit were combined to compare with medium dark green. Thus, medium dark green was dominant over light green. Weetman (1937) thought that other genes controlled fruit rind color from light to medium light green. This study also demonstrated that the shade of fruit rind color and the modifying characters (such as the greenish-white mottling on 'Long Iowa Belle' and the reticulation on 'Peacock Shipper' and 'Charleston Gray') are controlled by different gene loci.

In the family 'King\&Queen' (solid light green) $\times$ 'Peacock Shipper' (solid medium green), the $F_{1}$ had medium green rind with inconspicuous dark narrow stripes. The $F_{2}$ progeny segregated into 4 phenotypes: 31 light green with inconspicuous stripes (same 
Table 8. Single locus goodness-of-fit-test for stripe width in watermelon in family 'Black Diamond' (solid dark green) $\times$ 'Allsweet' (wide stripe) in trials at Kinston and Clinton, NC.

\begin{tabular}{lccccccrl}
\hline Generation & $\begin{array}{c}\text { Total } \\
\text { no. }^{\mathrm{z}}\end{array}$ & $\begin{array}{c}\text { Solid dark } \\
\text { green }^{\mathrm{y}}\end{array}$ & $\begin{array}{c}\text { Wide } \\
\text { stripe }^{\mathrm{x}}\end{array}$ & $\begin{array}{c}\text { No. } \\
\text { missing }\end{array}$ & $\begin{array}{c}\text { Expected } \\
\text { ratio }\end{array}$ & $\begin{array}{c}\text { Chi } \\
\text { square }\end{array}$ & df & Prob. \\
\hline $\mathrm{P}_{\mathrm{a}} \mathrm{S}_{1}$ & 20 & 20 & 0 & 0 & & & & \\
$\mathrm{P}_{\mathrm{b}} \mathrm{S}_{1}$ & 20 & 0 & 17 & 3 & & & & \\
$\mathrm{~F}_{1}$ & 40 & 40 & 0 & 0 & & & & \\
$\mathrm{~F}_{2}$ & 200 & 156 & 36 & 8 & $3: 1$ & 4.00 & 1 & 0.045 \\
$\mathrm{BC}_{1} \mathrm{P}_{\mathrm{a}}$ & 60 & 49 & 4 & 7 & $1: 0$ & 0.30 & 1 & $0.58^{*}$ \\
$\mathrm{BC}_{1} \mathrm{P}_{\mathrm{b}}$ & 60 & 35 & 24 & 1 & $1: 1$ & 2.05 & 1 & $0.15^{*}$ \\
\hline
\end{tabular}

${ }^{\mathrm{z}}$ Data were pooled over the two locations.

${ }^{\mathrm{y}}$ Solid dark green was dominant and $\mathrm{P}_{\mathrm{a}}$ was the carrier.

${ }^{\mathrm{x}}$ Wide stripe was recessive and $\mathrm{P}_{\mathrm{b}}$ was the carrier.

* Significant at the $0.05 P$ level.

Table 9. Single locus goodness-of-fit-test for fruit color in watermelon in family 'Peacock Shipper' (solid medium green) $\times$ 'Charleston Gray' (gray) in trials at Kinston and Clinton, NC.

\begin{tabular}{|c|c|c|c|c|c|c|c|c|}
\hline Generation & $\begin{array}{c}\text { Total } \\
\text { no. }^{z}\end{array}$ & $\begin{array}{l}\text { Solid medium } \\
\text { green }^{y}\end{array}$ & Gray $^{\mathrm{x}}$ & $\begin{array}{l}\text { No. } \\
\text { missing }\end{array}$ & $\begin{array}{l}\text { Expected } \\
\text { ratio }\end{array}$ & $\begin{array}{c}\text { Chi } \\
\text { square }\end{array}$ & df & Prob. \\
\hline$\overline{\mathrm{P}_{\mathrm{a}} \mathrm{S}_{1}}$ & 20 & 14 & 0 & 6 & & & & \\
\hline $\mathrm{P}_{\mathrm{b}} \mathrm{S}_{1}$ & 20 & 0 & 17 & 3 & & & & \\
\hline $\mathrm{F}_{1}$ & 40 & 37 & 0 & 3 & & & & \\
\hline $\mathrm{F}_{2}$ & 200 & 132 & 41 & 27 & $3: 1$ & 0.16 & 1 & $0.69 *$ \\
\hline $\mathrm{BC}_{1} \mathrm{P}_{\mathrm{a}}$ & 60 & 53 & 0 & 7 & $1: 0$ & 0.00 & 1 & $1.00 *$ \\
\hline $\mathrm{BC}_{1} \mathrm{P}_{\mathrm{b}}$ & 60 & 17 & 17 & 26 & $1: 1$ & 0.00 & 1 & $1.00 *$ \\
\hline
\end{tabular}

${ }^{2}$ Data were pooled over the two locations.

${ }^{\mathrm{y}}$ Solid medium green was dominant and $\mathrm{P}_{\mathrm{a}}$ was the carrier.

${ }^{\mathrm{x}}$ Gray was recessive and $\mathrm{P}_{\mathrm{b}}$ was the carrier.

* Significant at the $0.05 P$ level.

as 'King\&Queen'), 46 solid medium green (same as 'Peacock Shipper'), 45 medium green with narrow medium-green stripes, and 24 light green with narrow medium-green stripes. All $\mathrm{BC}_{1} \mathrm{P}_{\mathrm{a}}$ were like 'King\&Queen', while $\mathrm{BC}_{1} \mathrm{P}_{\mathrm{b}}$ segregated into 32 solid medium green and 18 light green with narrow mediumgreen stripes. If all striped fruit were combined, striped was a single gene, dominant over solid.

In the family 'Black Diamond' (solid dark green) $\times$ 'Charleston Gray' (gray), all $\mathrm{F}_{1}$ fruit had an intermediate rind color that was between the dark green of 'Black Diamond' and the light green of 'Charleston Gray'. In the $F_{2}$, various color shades between dark green and light green were observed, which indicated that solid color shade is controlled by multiple genes. In an earlier study, Porter (1937) investigated the inheritance of dark green and light green (or gray) in the family 'California Klondike' (similar to 'Black Diamond') $\times$ 'Thurmond Gray' (similar to 'Charleston Gray'), and found that the $F_{1}$ were intermediate green (lighter than 'California Klondike' but darker than 'Thurmond Gray'). The results were similar to ours, and also showed incomplete dominance of dark green over light green. Two other families investigated by Porter (1937): 'California Klondike' (solid dark green) $\times$ 'Snow Ball' (yellowish-white) and 'Angeleno Black Seeded' (solid dark green, similar to cultivar Black Diamond) $\times$ 'Snow Ball'. However, those families had complete dominance of the dark green color over yellowish-white color in the $F_{1}$. The ratio in the $F_{2}$ of 3 dark green: 1 yellowish-white also indicated a single gene, with dominance of dark green. Unfortunately, there were no backcrosses conducted to confirm the result, and no gene was named (Porter, 1937).
From the above, we concluded that 1) medium stripe of type-line 'Crimson Sweet' is a single gene, dominant over narrow stripe of type-line 'Red-N-Sweet' (Table 2), 2) wide stripe of type-lines 'Allsweet' and 'Tendersweet Orange Flesh' is a single gene, dominant over narrow stripe of type-line 'Red-N-Sweet' (Table 3), 3) narrow stripe of type-line 'Red-N-Sweet' is a single gene dominant over solid light green of type-line 'King\&Queen' (Table 4), 4) narrow stripe of type-line 'Red-N-Sweet' is a single gene, dominant over gray of type-line 'Charleston Gray' (Table 5), 5) solid medium green of type-line 'Peacock Shipper' is a single gene, dominant over medium stripe of type-line 'Crimson Sweet' (Table 6), 6) medium stripe of type-line 'Crimson Sweet' is a single gene, dominant over solid light green of type-line 'King\&Queen' (Table 7), 7) solid dark green of type-line 'Black Diamond' is a single gene, dominant over wide stripe of type-line 'Allsweet' (Table 8), and 8) solid medium green of type-line 'Peacock Shipper' is a single gene, dominant over gray of type-line 'Charleston Gray' (Table 9).

The type-line for the $G$ allele used by Weetman (1937) is not available. However, 'Peacock Shipper' and 'California Klondike' are selections of 'Klondike' (Wehner, 2002). There are three families in our study involving 'Peacock Shipper': 'Crimson Sweet' $\times$ 'Peacock Shipper', 'Peacock Shipper' $\times$ 'Charleston Gray', and 'King\&Queen' $\times$ 'Peacock Shipper'. There are two families involving cultivar Black Diamond with a phenotype similar to 'California Klondike'. Both 'Black Diamond' and 'California Klondike' have solid dark green rind. Although 'Peacock Shipper' has solid medium dark green rind that is lighter than the solid dark green in 'Black Diamond' and 'California Klondike', the solid green rind in 'Peacock Shipper' could be the same allele $G$ due to the close relationship between 'Peacock Shipper' and 'California Klondike'. The solid dark green in 'Black Diamond' could also be produced by allele $G$. For solid light green 'King\&Queen' and gray 'Charleston Gray', we suggest that the solid light green and gray phenotypes are produced by the same allele $g$ in the type-line 'Thurmond Gray', but further research is needed.

The $g$ locus was described earlier by Porter (1937) and Weetman (1937): $G$ is from 'California Klondike', $g^{s}$ is from 'Golden Honey', and $g$ is from 'Thurmond Gray'. We now add alleles to the locus as follows: $G$ (solid medium or dark green) from 'Peacock Shipper', 'Black Diamond', and 'California Klondike'; $g^{W}$ (wide stripe) is from 'Allsweet' and 'Tendersweet Orange Flesh'; $g^{M}$ (medium stripe) is from 'Crimson Sweet'; $g^{N}$ (narrow stripe) is from 'Red-NSweet'; and $g$ (solid light green or gray) is from 'King\&Queen', 'Charleston Gray' and 'Thurmond Gray'. $G$ (solid medium or dark green) is the most dominant; $g^{W}$ (wide stripe) is the second dominant and is only recessive to $G$ but dominant over the rest; $g^{M}$ (medium stripe) is the third dominant and is dominant over $g^{N}$ and $g$, but recessive to $\mathrm{G}$ and $g^{W} ; g^{N}$ (narrow stripe) is the fourth dominant; and $g$ (solid light green or gray) is the recessive. The $g^{S}$ allele from 'Golden Honey' may be the same as $g^{M}$ from 'Crimson Sweet', but additional crosses are needed to verify that.

Fruit stripe margin and color. Four families were studied for fruit stripe margin: 'PDS 808 ' (blurred fruit stripe margin) $\times$ 'Red-N-Sweet' (clear fruit stripe margin), 'Crimson Sweet' (blurred fruit stripe margin) $\times$ 'Red-N-Sweet' (clear fruit stripe margin), 'Allsweet' (blurred fruit stripe margin) $\times$ 'Red-N-Sweet'(clear fruit stripe margin), and 'Tendersweet Orange Flesh' (blurred fruit stripe margin) $\times$ 'Red-N-Sweet' (clear fruit stripe margin). One family, 'PDS $808^{\prime} \times$ 'Red-N-Sweet', did not have a Mendelian inheritance pattern (data not shown). In the other three families, we observed dominance of clear stripe margin in $F_{1}$ and a Mendelian segregation for a single gene in the $F_{2}$ and backcrosses, indicating that clear stripe margin was recessive to blurred stripe margin (Table 10). Stripe width was correlated with the stripe margin type. Blurred margins were observed only in medium and wide stripe fruits; clear margins were observed only in narrow stripe fruits. The $\operatorname{csm}$ gene is proposed for the clear stripe margin phenotype and is a single gene, recessive to blurred stripe margin $(C s m)$. The type-line for $c s m$ is 'RedN-Sweet', and Csm is from 'Crimson Sweet', 'Allsweet', and 'Tendersweet Orange Flesh'.

Stripe color was also evaluated in four families (Table 1): 'Crimson Sweet' (mediumgreen stripe) $\times$ 'Red-N-Sweet' (dark green stripe), 'Allsweet' (medium-green stripe) $\times$ 'Red-N-Sweet' (dark green stripe), 'Crimson Sweet' (medium-green stripe) $\times$ 'King\&Queen' (inconspicuous light green stripe), and 'Allsweet' (medium-green stripe) $\times$ 'King\&Queen' 
(inconspicuous light green stripe). However, no Mendelian inheritance pattern was observed.

Fruit shape. Weetman (1937) investigated the inheritance of fruit shape in 'Long Iowa Belle' (elongate) $\times$ 'Round Iowa Belle' and 'China 23' (round), 'Long Iowa Belle' (elongate) $\times$ 'Japan 6' and 'Japan 4' (round). He reported that elongate $(O O)$ was incompletely dominant to round $(o o)$ and the heterozygote $(\mathrm{Oo})$ was oval. We used two families with round fruit to verify allelism: 'Crimson Sweet' (round) $\times$ 'King\&Queen' (round) and 'Red-N-Sweet' (round) $\times$ 'King\&Queen' (round). No segregation was found in either of the families, suggesting that round fruit shape of 'Crimson Sweet', 'King\&Queen', and 'Red-N-Sweet' are controlled by the same gene.

Two families, 'Red-N-Sweet' (round) $x$ 'Tendersweet Orange Flesh' (oblong) and 'Crimson Sweet' (round) $\times$ 'Peacock Shipper' (oblong), were evaluated for inheritance of oblong fruit shape. In both families, all $\mathrm{F}_{1}$ fruit had round fruit shape which indicated that round fruit shape was dominant over oblong fruit shape. The $F_{2}$ progeny had 3 round: 1 oblong. The backcross to the oblong parent had 1 round fruit: 1 oblong fruit. All backcross to the round parent were round (Table 11). The data in both families suggested that the round shape of 'Red-N-Sweet' and 'Crimson Sweet' was a single gene, dominant over the oblong fruit shape of 'Tendersweet Orange Flesh' and 'Peacock Shipper'. Oblong is a homozygous recessive trait, and therefore, is not the same as oval $(\mathrm{Oo})$. We propose a new gene for round fruit of 'Red-N-Sweet' and 'Crimson Sweet' $\left(O b^{R}\right)$, dominant over the oblong fruit shape of 'Tendersweet Orange Flesh' and 'Peacock Shipper' $(o b)$.

In the family 'Peacock Shipper' (oblong) $\times$ 'Charleston Gray' (elongate), all $F_{1}$ fruit had elongate fruit. The $\mathrm{F}_{2}$ segregated into 3 elongate: 1 oblong. The $\mathrm{BC}_{1} \mathrm{P}_{\mathrm{a}}$ had 1 elongate: 1 oblong and the $\mathrm{BC}_{1} \mathrm{P}_{\mathrm{b}}$ were elongate (Table 12). The results suggest that the elongate fruit of 'Charleston Gray' is a single gene, dominant over oblong fruit of 'Peacock Shipper'. We propose a new allele for elongate fruit of 'Charleston Gray' $\left(O b^{E}\right)$, dominant over the oblong fruit shape of 'Peacock Shipper' $(o b)$.

In the family 'King\&Queen' (round) $\times$ 'Peacock Shipper' (oblong), all $F_{1}$ fruit were round but different from the round shape of 'King\&Queen'. There was segregation in $\mathrm{F}_{2}$ and $\mathrm{BC}_{1} \mathrm{P}_{\mathrm{b}}$, but the goodness-of-fit tests for the $\mathrm{F}_{2}, \mathrm{BC}_{1} \mathrm{P}_{\mathrm{a}}$, and $\mathrm{BC}_{1} \mathrm{P}_{\mathrm{b}}$ generations were not significant.

The $o$ gene was segregating in five families, 'Red-N-Sweet' (round) $\times$ 'Allsweet' (elongate), 'Red-N-Sweet' (round) $\times$ 'Charleston Gray' (elongate), 'Black Diamond' (round) $\times$ 'Allsweet' (elongate), 'Black Diamond' (round) $\times$ 'Charleston Gray' (elongate), and 'King\&Queen' (round) $\times$ 'Allsweet' (elongate). All $\mathrm{F}_{1}$ fruit had oval $(\mathrm{Oo})$ fruit shape. Although the goodness-of-fit tests for the $\mathrm{F}_{2}$ in family 'Black Diamond' × 'Charleston Gray'

Table 10. Single locus goodness-of-fit-test for stripe margin in watermelon for crossings involving blurred stripe margin $\times$ clear stripe margin in trials at Kinston and Clinton, NC.

\begin{tabular}{|c|c|c|c|c|c|c|c|c|}
\hline Generation & $\begin{array}{l}\text { Total } \\
\text { no. } .^{z}\end{array}$ & Blurred ${ }^{y}$ & Clear & $\begin{array}{c}\text { No. } \\
\text { missing }\end{array}$ & $\begin{array}{l}\text { Expected } \\
\text { ratio }\end{array}$ & $\begin{array}{l}\text { Chi } \\
\text { square }\end{array}$ & df & Prob. \\
\hline \multicolumn{9}{|c|}{ ‘Crimson Sweet’ (blurred stripe margin) × ‘Red-N-Sweet’ (clear stripe margin) } \\
\hline $\mathrm{P}_{\mathrm{a}} \mathrm{S}_{1}$ & 20 & 15 & 0 & 5 & & & & \\
\hline $\mathrm{P}_{\mathrm{b}} \mathrm{S}_{1}$ & 20 & 0 & 19 & 1 & & & & \\
\hline $\mathrm{F}_{1}$ & 40 & 34 & 0 & 6 & & & & \\
\hline $\mathrm{F}_{2}$ & 200 & 106 & 44 & 50 & $3: 1$ & 1.50 & 1 & $0.22 *$ \\
\hline $\mathrm{BC}_{1} \mathrm{P}_{\mathrm{a}}$ & 60 & 43 & 1 & 16 & 1:0 & 0.02 & 1 & $0.88^{*}$ \\
\hline $\mathrm{BC}_{1} \mathrm{P}_{\mathrm{b}}$ & 60 & 23 & 22 & 15 & $1: 1$ & 0.02 & 1 & $0.88^{*}$ \\
\hline \multicolumn{9}{|c|}{ 'Allsweet' (blurred stripe margin) $\times$ 'Red-N-Sweet' (clear stripe margin) } \\
\hline $\mathrm{P}_{\mathrm{a}} \mathrm{S}_{1}$ & 20 & 8 & 0 & 12 & & & & \\
\hline $\mathrm{P}_{\mathrm{b}} \mathrm{S}_{1}$ & 20 & 0 & 10 & 10 & & & & \\
\hline$F_{1}$ & 40 & 32 & 0 & 8 & & & & \\
\hline $\mathrm{F}_{2}$ & 200 & 101 & 35 & 64 & $3: 1$ & 0.04 & 1 & $0.84 *$ \\
\hline $\mathrm{BC}_{1} \mathrm{P}_{\mathrm{a}}$ & 60 & 45 & 0 & 15 & $1: 0$ & 0.00 & 1 & $1.00 *$ \\
\hline $\mathrm{BC}_{1} \mathrm{P}_{\mathrm{b}}$ & 60 & 15 & 15 & 30 & $1: 1$ & 0.00 & 1 & $1.00 *$ \\
\hline \multicolumn{9}{|c|}{ 'Tendersweet Orange Flesh' (blurred stripe margin) × 'Red-N-Sweet' (clear stripe margin) } \\
\hline $\mathrm{P}_{\mathrm{a}} \mathrm{S}_{1}$ & 20 & 20 & 0 & 0 & & & & \\
\hline $\mathrm{P}_{\mathrm{b}} \mathrm{S}_{1}$ & 20 & 0 & 13 & 7 & & & & \\
\hline $\mathrm{F}_{1}$ & 40 & 34 & 0 & 6 & & & & \\
\hline $\mathrm{F}_{2}$ & 200 & 120 & 39 & 41 & $3: 1$ & 0.02 & 1 & $0.89 *$ \\
\hline $\mathrm{BC}_{1} \mathrm{P}_{\mathrm{a}}$ & 60 & 54 & 0 & 6 & $1: 0$ & 0.00 & 1 & $1.00^{*}$ \\
\hline $\mathrm{BC}_{1} \mathrm{P}_{\mathrm{b}}$ & 60 & 31 & 25 & 4 & $1: 1$ & 0.64 & 1 & $0.42 *$ \\
\hline \multicolumn{9}{|l|}{ Pooled } \\
\hline $\mathrm{P}_{\mathrm{a}} \mathrm{S}_{1}$ & 60 & 43 & 0 & 17 & & & & \\
\hline $\mathrm{P}_{\mathrm{b}} \mathrm{S}_{1}$ & 60 & 0 & 42 & 18 & & & & \\
\hline $\mathrm{F}_{1}$ & 120 & 100 & 0 & 20 & & & & \\
\hline $\mathrm{F}_{2}$ & 600 & 327 & 118 & 155 & $3: 1$ & 0.59 & 1 & $0.44 *$ \\
\hline $\mathrm{BC}_{1} \mathrm{P}_{\mathrm{a}}$ & 180 & 142 & 1 & 37 & $1: 0$ & 0.01 & 1 & $0.92 *$ \\
\hline $\mathrm{BC}_{1} \mathrm{P}_{\mathrm{b}}$ & 180 & 69 & 62 & 49 & $1: 1$ & 0.37 & 1 & $0.54 *$ \\
\hline
\end{tabular}

${ }^{\mathrm{z}}$ Data were pooled over the two locations.

${ }^{\mathrm{y}}$ Blurred stripe margin was dominant and $\mathrm{P}_{\mathrm{a}}$ was the carrier.

${ }^{\mathrm{x}}$ Clear stripe margin was recessive and $\mathrm{P}_{\mathrm{b}}$ was the carrier.

*Significant at the $0.05 P$ level.

Table 11. Single locus goodness-of-fit-test for fruit shape in watermelon for crossings involving round fruit shape $\times$ oblong fruit shape in trials at Kinston and Clinton, NC.

\begin{tabular}{|c|c|c|c|c|c|c|c|c|}
\hline Generation & $\begin{array}{l}\text { Total } \\
\text { no. }{ }^{2}\end{array}$ & Round $^{y}$ & Oblong $^{x}$ & $\begin{array}{c}\text { No. } \\
\text { missing }\end{array}$ & $\begin{array}{l}\text { Expected } \\
\text { ratio }\end{array}$ & $\begin{array}{c}\text { Chi } \\
\text { square }\end{array}$ & df & Prob. \\
\hline \multicolumn{9}{|c|}{ 'Red-N-Sweet' (round) × 'Tendersweet Orange Flesh' (oblong) } \\
\hline $\mathrm{P}_{\mathrm{a}} \mathrm{S}_{1}$ & 20 & 13 & 0 & 7 & & & & \\
\hline $\mathrm{P}_{\mathrm{b}} \mathrm{S}_{1}$ & 20 & 2 & 18 & 0 & & & & \\
\hline $\mathrm{F}_{1}$ & 40 & 34 & 0 & 6 & & & & \\
\hline $\mathrm{F}_{2}$ & 200 & 129 & 31 & 40 & $3: 1$ & 2.70 & 1 & $0.10^{*}$ \\
\hline $\mathrm{BC}_{1} \mathrm{P}_{\mathrm{a}}$ & 60 & 56 & 0 & 4 & 1:0 & 0.00 & 1 & $1.00 *$ \\
\hline $\mathrm{BC}_{1} \mathrm{P}_{\mathrm{b}}$ & 60 & 30 & 24 & 6 & $1: 1$ & 0.67 & 1 & $0.41 *$ \\
\hline \multicolumn{9}{|c|}{ 'Crimson Sweet' (round) × 'Peacock Shipper' (oblong) } \\
\hline $\mathrm{P}_{\mathrm{a}} \mathrm{S}_{1}$ & 20 & 18 & 0 & 2 & & & & \\
\hline $\mathrm{P}_{\mathrm{b}} \mathrm{S}_{1}$ & 20 & 1 & 19 & 0 & & & & \\
\hline $\mathrm{F}_{1}$ & 40 & 35 & 4 & 1 & & & & \\
\hline $\mathrm{F}_{2}$ & 200 & 128 & 46 & 26 & $3: 1$ & 0.19 & 1 & $0.66^{*}$ \\
\hline $\mathrm{BC}_{1} \mathrm{P}_{\mathrm{a}}$ & 60 & 55 & 1 & 4 & $1: 0$ & 0.02 & 1 & $0.89^{*}$ \\
\hline $\mathrm{BC}_{1} \mathrm{P}_{\mathrm{b}}$ & 60 & 30 & 26 & 4 & $1: 1$ & 0.29 & 1 & $0.59 *$ \\
\hline \multicolumn{9}{|l|}{ Pooled } \\
\hline $\mathrm{P}_{\mathrm{a}} \mathrm{S}_{1}$ & 40 & 31 & 0 & 9 & & & & \\
\hline $\mathrm{P}_{\mathrm{b}} \mathrm{S}_{1}$ & 40 & 3 & 37 & 0 & & & & \\
\hline $\mathrm{F}_{1}$ & 80 & 69 & 4 & 7 & & & & \\
\hline $\mathrm{F}_{2}$ & 400 & 257 & 77 & 66 & $3: 1$ & 0.59 & 1 & $0.44 *$ \\
\hline $\mathrm{BC}_{1} \mathrm{P}_{\mathrm{a}}$ & 120 & 111 & 1 & 8 & 1:0 & 0.01 & 1 & $0.92 *$ \\
\hline $\mathrm{BC}_{1} \mathrm{P}_{\mathrm{b}}$ & 120 & 60 & 50 & 10 & $1: 1$ & 0.91 & 1 & $0.34 *$ \\
\hline
\end{tabular}

${ }^{2}$ Data were pooled over the two locations.

${ }^{\mathrm{y}}$ Round fruit shape was dominant and $\mathrm{P}_{\mathrm{a}}$ was the carrier.

${ }^{x}$ Oblong was recessive and $\mathrm{P}_{\mathrm{b}}$ was the carrier.

*Significant at the $0.05 P$ level.

and for the $\mathrm{BC}_{1} \mathrm{P}_{\mathrm{a}}$ in family were not significant, the results were consistent over the five families (Table 13).

From the above, we conclude that 1) round fruit of 'Red-N-Sweet' and 'Crimson Sweet' is a single gene, dominant over oblong fruit of 'Tendersweet Orange Flesh' and 'Peacock Shipper', 2) elongate fruit of 'Charleston Gray' is a single gene, dominant over oblong fruit of 'Peacock Shipper'. From both earlier study and our experiment, we know that elongate fruit shape $(O O)$ was incompletely dominant to round fruit shape $(o o)$ and the heterozygote $(\mathrm{Oo})$ was oval shaped (Weetman, 1937; Poole and Grimball 1945). Therefore, we propose that the oblong fruit is controlled by a new allele in homozygous recessive condition. We suggest $O b^{R}$ 
Table 12. Single locus goodness-of-fit-test for fruit shape in watermelon in family 'Charleston Gray' (elongate) $\times$ 'Peacock Shipper' (oblong) in trials at Kinston and Clinton, NC.

\begin{tabular}{|c|c|c|c|c|c|c|c|c|}
\hline Generation & $\begin{array}{l}\text { Total } \\
\text { no. }^{\mathrm{z}}\end{array}$ & Elongate $^{\mathrm{y}}$ & Oblong $^{x}$ & $\begin{array}{c}\text { No. } \\
\text { missing }\end{array}$ & $\begin{array}{c}\text { Expected } \\
\text { ratio }\end{array}$ & $\begin{array}{c}\text { Chi } \\
\text { square }\end{array}$ & $\mathrm{df}$ & Prob. \\
\hline $\mathrm{P}_{\mathrm{a}} \mathrm{S}_{1}$ & 20 & 15 & 1 & 4 & & & & \\
\hline $\mathrm{P}_{\mathrm{b}} \mathrm{S}_{1}$ & 20 & 0 & 12 & 8 & & & & \\
\hline $\mathrm{F}_{1}$ & 40 & 37 & 0 & 3 & & & & \\
\hline $\mathrm{F}_{2}$ & 200 & 128 & 44 & 28 & $3: 1$ & 0.03 & 1 & $0.86^{*}$ \\
\hline $\mathrm{BC}_{1} \mathrm{P}_{\mathrm{a}}$ & 60 & 31 & 2 & 26 & $1: 0$ & 0.12 & 1 & $0.73 *$ \\
\hline $\mathrm{BC}_{1} \mathrm{P}_{\mathrm{b}}$ & 60 & 21 & 31 & 8 & $1: 1$ & 1.92 & 1 & $0.17^{*}$ \\
\hline
\end{tabular}

${ }^{z}$ Data were pooled over the two locations.

${ }^{y}$ Elongate fruit shape was dominant and $\mathrm{P}_{\mathrm{a}}$ was the carrier.

${ }^{\mathrm{x}}$ Oblong fruit shape was recessive and $\mathrm{P}_{\mathrm{b}}$ was the carrier.

* Significant at the $0.05 P$ level.

Table 13. Single locus goodness-of-fit-test for fruit shape in watermelon for crossings involving round fruit shape $\times$ elongate fruit shape in trials at Kinston and Clinton, NC.

\begin{tabular}{|c|c|c|c|c|c|c|c|c|c|}
\hline Generation & $\begin{array}{c}\text { Total } \\
\text { no. }^{z}\end{array}$ & $\begin{array}{c}\text { Elongate } \\
O O\end{array}$ & $\begin{array}{c}\text { Oval }^{y} \\
\text { Oo }\end{array}$ & $\begin{array}{c}\text { Round } \\
\text { oo }\end{array}$ & $\begin{array}{c}\text { No. } \\
\text { missing }\end{array}$ & $\begin{array}{l}\text { Expected } \\
\text { ratio }\end{array}$ & $\begin{array}{c}\text { Chi } \\
\text { square }\end{array}$ & df & Prob. \\
\hline \multicolumn{10}{|c|}{ 'Allsweet' (elongate) × 'Red-N-Sweet' (round) } \\
\hline $\mathrm{P}_{\mathrm{a}} \mathrm{S}_{1}$ & 20 & 8 & 0 & 0 & 12 & & & & \\
\hline $\mathrm{P}_{\mathrm{b}} \mathrm{S}_{1}$ & 20 & 0 & 0 & 10 & 10 & & & & \\
\hline $\mathrm{F}_{1}$ & 40 & 2 & 30 & 0 & 8 & & & & \\
\hline $\mathrm{F}_{2}$ & 200 & 30 & 67 & 34 & 69 & $1: 2: 1$ & 0.36 & 2 & $0.84 *$ \\
\hline $\mathrm{BC}_{1} \mathrm{P}_{\mathrm{a}}$ & 60 & 21 & 24 & 0 & 15 & $1: 1: 0$ & 0.09 & 1 & $0.76^{*}$ \\
\hline $\mathrm{BC}_{1} \mathrm{P}_{\mathrm{b}}$ & 60 & 1 & 13 & 16 & 30 & $0: 1: 1$ & 0.33 & 1 & $0.57 *$ \\
\hline \multicolumn{10}{|c|}{ 'Allsweet' (elongate) $\times$ 'Black Diamond' (round) } \\
\hline $\mathrm{P}_{\mathrm{a}} \mathrm{S}_{1}$ & 20 & 17 & 0 & 0 & 3 & & & & \\
\hline $\mathrm{P}_{\mathrm{b}} \mathrm{S}_{1}$ & 20 & 0 & 0 & 20 & 0 & & & & \\
\hline $\mathrm{F}_{1}$ & 40 & 0 & 40 & 0 & 0 & & & & \\
\hline $\mathrm{F}_{2}$ & 200 & 37 & 100 & 54 & 9 & $1: 2: 1$ & 3.00 & 2 & $0.22 *$ \\
\hline $\mathrm{BC}_{1} \mathrm{P}_{\mathrm{a}}$ & 60 & 28 & 30 & 1 & 1 & $1: 1: 0$ & 0.07 & 1 & $0.79 *$ \\
\hline $\mathrm{BC}_{1} \mathrm{P}_{\mathrm{b}}$ & 60 & 2 & 29 & 22 & 7 & $0: 1: 1$ & 0.74 & 1 & $0.39 *$ \\
\hline \multicolumn{10}{|c|}{ 'Allsweet' (elongate) $\times$ 'King\&Queen' (round) } \\
\hline $\mathrm{P}_{\mathrm{a}} \mathrm{S}_{1}$ & 20 & 19 & 1 & 0 & 0 & & & & \\
\hline $\mathrm{P}_{\mathrm{b}} \mathrm{S}_{1}$ & 20 & 0 & 0 & 19 & 1 & & & & \\
\hline $\mathrm{F}_{1}$ & 40 & 1 & 34 & 1 & 4 & & & & \\
\hline $\mathrm{F}_{2}$ & 200 & 44 & 96 & 41 & 19 & $1: 2: 1$ & 0.65 & 2 & $0.72 *$ \\
\hline $\mathrm{BC}_{1} \mathrm{P}_{\mathrm{a}}$ & 60 & 27 & 26 & 2 & 5 & $1: 1: 0$ & 0.01 & 1 & $0.92 *$ \\
\hline $\mathrm{BC}_{1} \mathrm{P}_{\mathrm{b}}$ & 60 & 0 & 46 & 13 & 1 & $0: 1: 1$ & 17.4 & 1 & 0.00 \\
\hline \multicolumn{10}{|c|}{ 'Charleston Gray' (elongate) × 'Red-N-Sweet' (round) } \\
\hline $\mathrm{P}_{\mathrm{a}} \mathrm{S}_{1}$ & 20 & 8 & 0 & 0 & 12 & & & & \\
\hline $\mathrm{P}_{\mathrm{b}} \mathrm{S}_{1}$ & 20 & 0 & 0 & 19 & 1 & & & & \\
\hline $\mathrm{F}_{1}$ & 40 & 0 & 29 & 1 & 10 & & & & \\
\hline $\mathrm{F}_{2}$ & 200 & 36 & 86 & 44 & 34 & $1: 2: 1$ & 0.58 & 2 & $0.75 *$ \\
\hline $\mathrm{BC}_{1} \mathrm{P}_{\mathrm{a}}$ & 60 & 25 & 31 & 0 & 4 & $1: 1: 0$ & 0.64 & 1 & $0.42 *$ \\
\hline $\mathrm{BC}_{1} \mathrm{P}_{\mathrm{b}}$ & 60 & 0 & 29 & 25 & 6 & $0: 1: 1$ & 0.30 & 1 & $0.58^{*}$ \\
\hline \multicolumn{10}{|c|}{ 'Charleston Gray' (elongate) $\times$ 'Black Diamond' (round) } \\
\hline $\mathrm{P}_{\mathrm{a}} \mathrm{S}_{1}$ & 20 & 14 & 1 & 1 & 4 & & & & \\
\hline $\mathrm{P}_{\mathrm{b}} \mathrm{S}_{1}$ & 20 & 0 & 0 & 18 & 2 & & & & \\
\hline $\mathrm{F}_{1}$ & 40 & 0 & 27 & 11 & 2 & & & & \\
\hline $\mathrm{F}_{2}$ & 200 & 26 & 93 & 56 & 25 & $1: 2: 1$ & 10.91 & 2 & 0.004 \\
\hline $\mathrm{BC}_{1} \mathrm{P}_{\mathrm{a}}$ & 60 & 25 & 30 & 2 & 3 & $1: 1: 0$ & 0.17 & 1 & $0.68 *$ \\
\hline $\mathrm{BC}_{1} \mathrm{P}_{\mathrm{b}}$ & 60 & 0 & 27 & 32 & 1 & $0: 1: 1$ & 0.27 & 1 & $0.60 *$ \\
\hline \multicolumn{10}{|c|}{ Pooled (elongate $\times$ round) } \\
\hline $\mathrm{P}_{\mathrm{a}} \mathrm{S}_{1}$ & 100 & 66 & 2 & 1 & 31 & & & & \\
\hline $\mathrm{P}_{\mathrm{b}} \mathrm{S}_{1}$ & 100 & 0 & 0 & 86 & 14 & & & & \\
\hline $\mathrm{F}_{1}$ & 100 & 3 & 160 & 13 & 24 & & & & \\
\hline $\mathrm{F}_{2}$ & 1000 & 173 & 442 & 229 & 156 & $1: 2: 1$ & 9.33 & 2 & 0.01 \\
\hline $\mathrm{BC}_{1} \mathrm{P}_{\mathrm{a}}$ & 300 & 126 & 141 & 5 & 28 & $1: 1: 0$ & 0.92 & 1 & $0.34 *$ \\
\hline $\mathrm{BC}_{1} \mathrm{P}_{\mathrm{b}}$ & 300 & 3 & 144 & 108 & 45 & $0: 1: 1$ & 5.11 & 1 & 0.02 \\
\hline
\end{tabular}

${ }^{\mathrm{z}}$ Data were pooled over the two locations.

${ }^{y}$ The heterozygote has intermediate oval fruit shape.

* Significant at the $0.05 P$ level.

for round fruit shape, $O b^{E}$ for elongate fruit, and $o b$ for oblong fruit. Elongate fruit $\left(O b^{E}\right.$ $\left.O b^{E}\right)$ is dominant over round fruit $\left(O b^{R} O b^{R}\right)$ and oblong fruit; round fruit is completely dominant over oblong fruit but recessive to elongate fruit; and oblong fruit $(o b o b)$ is homozygous recessive. The type-line for $O b^{E}$ is 'Charleston Gray'; type-lines for $O b^{R}$ are 'Red-N-Sweet' and 'Crimson Sweet'; and combine research on qualitative and molecular genetics.

Fruit furrowing. Furrowed fruit surface (f) was found to be recessive to smooth surface $(F)$ (Poole, 1944, Wehner, 2008a). However, the type-lines were not given in the original reference. Three families were investigated to study this gene, 'Crimson Sweet' (smooth fruit surface) $\times$ 'Peacock Shipper' (furrowed fruit surface), 'Allsweet' (smooth fruit surface) $\times$ 'Black Diamond' (furrowed fruit surface), and 'Peacock Shipper' (furrowed fruit surface) $\times$ 'Charleston Gray' (smooth fruit surface) (Table 1). However, no Mendelian inheritance pattern was observed.

\section{Conclusions}

We have identified new genes or alleles that control external fruit traits. Such information can be used for breeding watermelons with desired appearance, as described below.

Fruit stripe. A more complete series of alleles at the $g$ locus of five alleles is proposed to explain the inheritance of fruit rind pattern and color: $G$ (solid medium or dark green), $g^{W}$ (wide stripe), $g^{M}$ (medium stripe), $g^{N}$ (narrow stripe), and $g$ (solid light green or gray). Their dominance is $G>g^{W}>g^{M}>g^{N}>g$. The following type-lines are proposed: $G G$ for solid medium or dark green of 'Peacock Shipper', 'Black Diamond', as well as 'California Klondike'; $g^{W} g^{W}$ for wide stripe of 'Allsweet' and 'Tendersweet Orange Flesh'; $g^{M} g^{M}$ for medium stripe of 'Crimson Sweet'; $g^{N} g^{N}$ for narrow stripe of 'Red-N-Sweet'; and $g g$ for gray or solid light green of 'Charleston Gray' and 'King\&Queen'. The difference between the solid light green of 'King\&Queen' and the gray of 'Charleston Gray' needs further investigation. An allelism test between wide stripe and medium stripe is also needed. Future studies might include the following families: 1) 'Allsweet' (wide stripe) $\times$ 'Peacock Shipper' (solid medium green), 2) 'Allsweet' (wide stripe) $\times$ 'Crimson Sweet' (medium stripe), and 3) 'King\&Queen' (light green) $\times$ 'Charleston Gray' (gray).

The solid dark green rind in 'Black Diamond' was evaluated. The intermediate rind pattern in the $F_{1}$ and the continuous green shades in the $F_{2}$ indicate that the background color shade and stripe are controlled by different genes and solid color shade is controlled by multiple genes.

Fruit stripe margin and color. The blurred stripe margin is found to be controlled by a single gene that is dominant over clear stripe margin. We proposed the gene name csm for the clear stripe margin in the cultivar Red-N-Sweet and it is recessive to the blurred stripe margin $(\mathrm{Csm})$ in cultivars Crimson Sweet, Allsweet, and Tendersweet Orange Flesh. No inheritance pattern was found for stripe color in our studies.

Fruit shape. A series of three alleles at the $o b$ locus is proposed for fruit shape: $O b^{E}$ for elongate fruit, $O b^{R}$ (not the same as the $o$ gene) for the round fruit shape, and $o b$ for 
oblong fruit being most recessive. Elongate fruit $\left(O b^{E} O b^{E}\right)$ of 'Charleston Gray' is dominant over round fruit $\left(O b^{R} O b^{R}\right)$ and oblong fruit; round fruit of 'Red-N-Sweet' and 'Crimson Sweet' is dominant over oblong fruit but recessive to elongate fruit; and oblong fruit $(a b o b)$ of 'Tendersweet Orange Flesh' and 'Peacock Shipper' is recessive.

Fruit blossom end and furrowing. The inheritance of the two different kinds of blossom end, concave and convex, was investigated in this experiment. However, a single gene inheritance pattern was not detected.

\section{Literature Cited}

Arumuganathan, K. and E.D. Earle. 1991. Nuclear DNA content of some important plant species. Plant Mol. Biol. Rpt. 9:208-219.

Barham, W.S. 1956. A study of the Royal Golden watermelon with emphasis on the inheritance of the chlorotic condition characteristic of this variety. Proc. Amer. Soc. Hort. Sci. 67:487-489.

Cucurbit Gene List Committee. 1982. Update of cucurbit gene list and nomenclature rules. Rpt. Cucurbit Genet. Coop. 5:62-66.

Guner, N. and T.C. Wehner. 2003. Gene list for watermelon. Rpt. Cucurbit Genet. Coop. 26: 76-92.

Guner, N. and T.C. Wehner. 2004. The genes of watermelon. HortScience 39:1175-1182.

Guo, S., J. Zhang, H. Sun, J. Salse, W.J. Lucas, H. Zhang, Y. Zheng, L. Mao, Y. Ren, Z. Wang, J. Min, X. Guo, F. Murat, B.K. Ham, Z. Zhang, S. Gao, M. Huang, Y. Xu, S. Zhong, A. Bombarely, L.A. Mueller, H. Zhao, H. He, Y. Zhang, Z. Zhang, S. Huang, T. Tan, E. Pang, K. Lin, Q. Hu, H. Kuang, P. Ni, B. Wang, J. Liu, Q. Kou, W. Hou, X. Zou, J. Jiang, G. Gong, K. Klee,
H. Schoof, Y. Huang, X. Hu, S. Dong, D. Liang, J. Wang, K. Wu, Y. Xia, X. Zhao, Z. Zheng, M. Xing, X. Liang, B. Huang, T. Lv, J. Wang, Y. Yin, H. Yi, R. Li, M. Wu, A. Levi, X. Zhang, J.J. Giovannoni, J. Wang, Y. Li, Z. Fei, and Y. Xu. 2013. The draft genome of watermelon (Citrullus lanatus) and resequencing of 20 diverse accessions. Natl. Genet. 45:51-58.

Gusmini, G. and T.C. Wehner. 2006a. Qualitative inheritance of rind pattern and flesh color in watermelon. J. Hered. 97:177-185.

Gusmini, G. and T.C. Wehner. 2006b. Review of watermelon genetics for plant breeders. Cucurbit Genet. Coop. Rpt. 28-29:52-61.

Kenny, I.J. and D.R. Porter. 1941. Relative rind toughness among watermelon varieties. Proc. Amer. Soc. Hort. Sci. 38:537-540.

Korn, R.W. 2007. Watermelon Stripes. A case for the Clonal Mosaic Model in Plants. J. Theor. Biol. 247:859-861.

Kumar, R. and T.C. Wehner. 2011. Discovery of second gene for solid dark green versus light green rind pattern in watermelon. J. Hered. 102:489-493.

Liu, J.S., T.C. Wehner, and S.B. Donaghy. 1997. SASGENE: A SAS computer program for genetic analysis of gene segregation and linkage. J. Hered. 88:253-254.

Maynard, D.N. (ed.). 2001. Watermelons. Characteristics, production, and marketing. ASHS Press, Alexandria, Virginia.

Poole, C.F. 1944. Genetics of cultivated cucurbits. J. Hered. 35:122-128.

Poole, C.F. and P.C. Grimball. 1945. Interaction of sex, shape, and weight genes in watermelon. J. Agr. Res. 71:533-552.

Porter, D.R. 1937. Inheritance of certain fruit and seed characters in watermelons. Hilgardia 10:489-509.

Rhodes, B. 1986. Gene affecting foliage color in watermelon. J. Hered. 77:134-135.
Robinson, R.W., H.M. Munger, T.W. Whitaker, and G.W. Bohn. 1976. Genes of the Cucurbitaceae. HortScience 11:554-568.

Sanders, D.C. (ed.). 2004. Vegetable crop guidelines for the Southeastern U.S. 2004-2005, pp. 1-215. North Carolina Vegetable Growers Association, Raleigh, NC.

Sandlin, K., J. Prothro, A. Heesacker, N. Khalilian, R. Okashah, W. Xiang, E. Bachlava, D.G. Caldwell, C.A. Taylor, D.K. Seymour, V. White, E. Chan, G. Tolla, C. White, D. Safran, E. Graham, S. Knapp, and C. McGregor. 2012. Comparative mapping in watermelon [Citrullus lanatus (Thunb.) Matsum. et Nakai]. Theor. Appl. Genet. 125:1603-1618.

United States Department of Agriculture. 2004 Statistics of vegetables and melons. U.S. Dept. Agr., Washington D.C.

United States Department of Agriculture. 2012. Statistics of vegetables and melons. U.S. Dept. Agr., Washington D.C.

Weetman, L.M. 1937. Inheritance and correlation of shape, size and color in the watermelon, Citrullus vulgaris Schrad. Iowa Agr. Expt. Stat. Ann. Bul. 228:224-256.

Wehner, T.C. 2002. Vegetable cultivar descriptions for North America, lists 1-26 combined. $<$ http://cuke.hort.ncsu.edu/cucurbit/wehner/ vegcult/vgclintro.html $>$.

Wehner, T.C. 2008a. Overview of the genes of watermelon. Proc. Cucurbitaceae 2008. M. Pitrat (ed.). EUCARPIA Meeting, p. 79-89.

Wehner, T.C. 2008b. Watermelon, p. 381-418. In: J. Prohens and F. Nuez (eds.). Handbook of plant breeding; Vegetables I: Asteraceae, Brassicaceae, Chenopodiaceae, and Cucurbitaceae, 426 p. 17. Springer Science+Business LLC, New York, NY

Wehner, T.C. 2012. The genes of watermelon. Cucurbit Genetics Coop. Rpt. 36:40-64. 